\title{
Accelerated Hippocampal Spreading Depression and Enhanced Locomotory Activity in Mice with Astrocyte-Directed Inactivation of Connexin 43
}

\author{
Martin Theis, ${ }^{1}$ Regina Jauch, ${ }^{2}$ Lang Zhuo, ${ }^{3}$ Dina Speidel, ${ }^{1}$ Anke Wallraff, ${ }^{5}$ Britta Döring, ${ }^{1}$ Christian Frisch, ${ }^{4}$ Goran Söhl, ${ }^{1}$ \\ Barbara Teubner, ${ }^{1}$ Carsten Euwens, ${ }^{1}$ Joseph Huston, ${ }^{4}$ Christian Steinhäuser, ${ }^{5}$ Albee Messing, ${ }^{3}$ Uwe Heinemann, ${ }^{2}$ and \\ Klaus Willecke ${ }^{1}$ \\ ${ }^{1}$ Institut für Genetik, Abteilung Molekulargenetik, Universität Bonn, D-53117 Bonn, Germany, ${ }^{2}$ Institut für Neurophysiologie der Charité, Abteilung \\ Neurophysiologie, D-10117 Berlin, Germany, ${ }^{3}$ Waisman Center and School of Veterinary Medicine, University of Wisconsin-Madison, Madison, Wisconsin \\ 53705-2280, ${ }^{4}$ Institut für Physiologische Psychologie, Universität Düsseldorf, D-40225 Düsseldorf, Germany, and ${ }^{5}$ Experimental Neurobiology, \\ Neurosurgery, University of Bonn, D-53105 Bonn, Germany
}

\begin{abstract}
Using a human glial fibrillary acidic protein (hGFAP) promoter-driven cre transgene, we have achieved efficient inactivation of a floxed connexin43 (Cx43) gene in astrocytes of adult mice. The loss of $\mathrm{Cx} 43$ expression was monitored in a cell-autonomous manner via conditional replacement of the $\mathrm{Cx} 43$-coding region by a lacZ reporter gene. In this way, we bypassed the early postnatal lethality previously reported for $\mathrm{Cx} 43$ null mice and characterized the phenotypic consequences of $\mathrm{Cx} 43$ deficiency in the CNS. Mice lacking Cx43 in astrocytes were viable and showed no evidence of either neurodegeneration or astrogliosis. Spreading depression (SD) is a pathophysiological phenomenon observed in the CNS that is characterized by a propagating wave of depolarization followed by neuronal inactivation. Inhibitors of gap junctional communication have previously been shown to block initiation and propagation of SD. In contrast, we observed an increase in the velocity of hippocampal SD in the stratum radiatum of mice lacking Cx43 in astrocytes. In the same brain subregion, dye-coupling experiments revealed a reduction in overall astrocytic intercellular communication by $\sim 50 \%$. This strongly suggests separate and different neuronal and glial contributions of gap junctional intercellular communication to SD. Concomitant with increased velocity of spreading depression, we observed enhanced locomotory activity in mice lacking Cx43 in astrocytes.
\end{abstract}

Key words: Cx43; Cre/loxP; spreading depression; behavior; dye coupling; hippocampal astrocytes

\section{Introduction}

Gap junctions are intercellular channels that allow diffusion of small molecules up to $1 \mathrm{kDa}$, such as metabolites, ions, and second messengers (Loewenstein, 1981). Vertebrate gap junction channels are composed of 12 protein subunits, called connexins. Six connexin proteins constitute a hemichannel, and two apposed cells each contribute a hemichannel to form a gap junctional intercellular channel (Kumar and Gilula, 1996).

Connexin43 ( $\mathrm{Cx} 43)$ is abundantly expressed in astrocytes of the adult brain and provides the major part of their extensive intercellular coupling (Dermietzel et al., 1989). Cx30 and Cx26 have also been detected in adult astrocytes at a lower expression level (Rash et al., 2000; Nagy et al., 2001). In astrocyte cultures, $\mathrm{Cx} 43$ was the predominant connexin isoform, accompanied by Cx40, Cx45, and Cx46 (Dermietzel et al., 2000).

\footnotetext{
Received Sept. 20, 2002; revised Nov. 7, 2002; accepted Nov. 8, 2002.

M.T. received a stipend from Graduiertenkolleg "Pathogenese von Krankheiten des Nervensystems." This work was supported by grants from the German Research Association (SFB 400, B3 and SFB TR-3, (1) and by Funds of the Chemical Industry to K.W. and C.S. We thank Xiaohua Gong and Shang-Zhi Xu for sharing unpublished data, Otto Traub and Christian Schlieker for providing connexin antibodies, and Gabriele Matern for technical assistance.

Correspondence should be addressed to Dr. Klaus Willecke, Institut für Genetik, Abteilung Molekulargenetik, Universität Bonn, Römerstrasse 164, D-53117 Bonn, Germany. E-mail: genetik@uni-bonn.de.

M. Theis's present address: Howard Hughes Medical Institute, Center for Neurobiology and Behavior, Columbia University, 1051 Riverside Drive, New York, NY 10032.

D. Speidel's present address: Max-Planck-Institut für Experimentelle Medizin, Abteilung Molekulare Neurobiologie, Hermann-Rein-Strasse 3, D-37075 Göttingen, Germany.

Copyright $\odot 2003$ Society for Neuroscience $\quad 0270-6474 / 03 / 230766-11 \$ 15.00 / 0$
}

Connexins were implicated in the propagation of astrocytic intercellular $\mathrm{Ca}^{2+}$ waves and their proposed in vivo correlate, the so-called spreading depression (SD) (cf. Martins-Ferreira et al., 2000). SD is a wave of neuronal inactivation moving through intact brain tissue and associated with epileptiform activity and migraine (Martins-Ferreira et al., 2000; James et al., 2001). Cx43deficient astrocyte cultures showed decreased propagation of calcium waves (Naus et al., 1997; Scemes et al., 1998), although lack of $\mathrm{Cx} 43$ might be compensated for by extracellular purinergic signaling and by other connexins (Scemes et al., 1998; Cotrina et al., 2000). Interestingly, a wave of astrocytic calcium increments precedes the depolarization wave of SD by several seconds (Basarsky et al., 1998; Kunkler and Kraig, 1998). In addition, inhibitors of gap junctional coupling likewise inhibit formation and propagation of SD and of calcium waves (Nedergaard et al., 1995; Martins-Ferreira et al., 2000). Therefore, mice lacking Cx43 in astrocytes might show impaired propagation of SD.

A contribution of neuronal gap junctional communication in this process is also possible (Largo et al., 1997), however, and the inhibitors used are not specific for connexin isoforms. Moreover, astrocytic gap junctions might even attenuate the propagation of SD by facilitating the uptake of potassium ions (Orkand et al., 1966; Ransom, 1996; Amzica et al., 2002) and glutamate (Blanc et al., 1998; Hansson et al., 2000) that are released during the depolarization phase of SD (Martins-Ferreira et al., 2000). Astrocytic gap junctions could actually counteract the attainment of a 
threshold level in the potassium ion or glutamate concentration that drives propagation of SD. Therefore, mice lacking $\mathrm{Cx} 43$ in astrocytes might show accelerated SD.

Because the systemic deletion of $C x 43$ causes early postnatal death (Reaume et al., 1995), we performed a conditional replacement of Cx43 by a lacZ reporter gene (Theis et al., 2001). To study the role of $\mathrm{Cx} 43$ in astrocytic intercellular signaling in the CNS of adult mice as well as changes in SD and their consequences for animal behavior, we achieved an astrocyte-directed inactivation of Cx43 using a human glial fibrillary acidic protein (hGFAP)-cre transgene (Zhuo et al., 2001). We observed an increased velocity of spreading depression and decreased astroglial dye coupling in the hippocampus. Behaviorally, the inactivation of $\mathrm{Cx} 43$ in astrocytes led to increases in locomotor activity in the open field.

\section{Materials and Methods \\ Generation of mice}

Mice lacking $\mathrm{Cx} 43$ in astrocytes or endothelial cells were obtained by interbreeding of $\mathrm{Cx} 43^{\mathrm{fl}}$ mice (Theis et al., 2001) with mice carrying the hGFAP-cre (Zhuo et al., 2001) or receptor tyrosine kinase II in endothelium (TIE2)-cre transgenes (Theis et al., 2001), respectively. Parental generations used for phenotypical investigation of the offspring were as follows: $\mathrm{Cx} 43^{\mathrm{fl} / \mathrm{fl}} \times \mathrm{Cx} 43^{+/}$, hGFAP-cre and $\mathrm{Cx} 43^{\mathrm{fl} / \mathrm{fl}} \times \mathrm{Cx} 43^{\mathrm{fl} / \mathrm{fl}}$, hGFAP-cre. Mice from the $\mathrm{Cx} 43^{\mathrm{del}}$ strain, carrying a lacZ gene in place of the $C x 43$ coding region (Theis et al., 2001), were used for comparison of cell type-specific lac $Z$ expression patterns with the total $C x 43$ genedriven lac $Z$ expression. TIE2-cre mice were used to demonstrate the endothelial subcompartment of Cx43 expression by $\beta$-galactosidase (XGal) staining (Theis et al., 2001).

\section{Nucleic acid analysis}

For detection of all cre transgenes used in this study, a general cre PCR was applied. Primers $5^{\prime}$-AAC CTG AAG ATG TTC GCG-3' and 5' -TAA TCG CCA TCT TCC AGC-3' were used, generating an 832 bp amplicon of part of the cre-coding region. PCR conditions were $1 \mathrm{mM} \mathrm{MgCl}, 30$ cycles of $1 \mathrm{~min}$ at $92^{\circ} \mathrm{C}, 1 \mathrm{~min}$ at $58^{\circ} \mathrm{C}$, and $1 \mathrm{~min}$ at $72^{\circ} \mathrm{C}$. In addition, transgene-specific PCRs were applied, i.e., the TIE2-cre PCR (Theis et al., 2001) and the hGFAP-cre PCR (Zhuo et al., 2001). The $C x 43^{f l}$ allele was detected by the Cx43flox PCR (Theis et al., 2001), the $C x 43^{\text {del }}$ allele by use of the 43del PCR (Theis et al., 2001), and the $C x 43^{-}$allele (Reaume et al., 1995) by the Cx43KO PCR (Houghton et al., 1999). Southern blot and Northern blot analysis were performed as described previously (Theis et al., 2001), except that after digestion with HindIII, fragments diagnostic of the $C x 43^{f l}$ allele and the $C x 43^{d e l}$ allele were detected by hybridization to a HindIII/ClaI fragment from pHM4 (Kästner et al., 1994) as a probe, spanning $900 \mathrm{bp}$ of the $5^{\prime} \beta$-Gal coding region.

\section{Immunodetection and histochemistry}

$\mathrm{X}$-Gal staining, Cx43-immunoblot analysis, and immunofluorescence analysis on cryosections using antibodies directed to $\mathrm{Cx} 43$ and $\beta$-Gal were performed as described previously (Theis et al., 2001). Cell-type specificity of $\beta$-Gal expression was determined by double staining with antibodies directed to $\beta$-Gal (Theis et al., 2001) and NeuN, a panneuronal antigen (Chemicon, Temecula, CA; diluted 1:50) or GFAP (Sigma, Taufkirchen, Germany; diluted 1:400), the latter two visualized by 5-(4.6-dichlorotriacinyl)-coupled secondary sheep anti-mouse IgG antibodies (Dianova, Hamburg, Germany; diluted 1:100). For immunocytochemistry, astrocyte cultures were fixed for $15 \mathrm{~min}$ in ice-cold methanol. Immunofluorescence and immunoblot analyses, with the respective dilutions mentioned in parentheses, were performed as described for $\mathrm{Cx} 43$ (Theis et al., 2001) using rabbit polyclonal antibodies directed to Cx26 (Gabriel et al., 1998) (1:500/1:500), Cx30 (Zymed, South San Francisco, CA) (1:500/1:250), Cx40 (Kirchhoff et al., 1998) (1:200/1:500), and Cx45 (Butterweck et al., 1994; Krüger et al., 2000) (1:200/1:500). For immunoblot analysis, protein concentration was determined using a bicinchoninic acid kit (Sigma). Equal loading and transfer efficiency were controlled by Ponceau staining of the membrane after blotting. For analysis of astrocyte density in adult mice, immunofluorescence staining on cryo- sections was performed using a monoclonal mouse GFAP antibody directly coupled to $\mathrm{Cy} 3$ (Sigma) as described above, including counterstaining with Hoechst 33258 (Sigma) (Theis et al., 2001). The number of GFAP-immunoreactive cells was counted in microscopic fields of $220 \times$ $174 \mu \mathrm{m}$ from the stratum radiatum of the CA1 region of $20-\mu \mathrm{m}$-thick coronary sections (bregma 1.70-2.46 mm). Significant differences between data were evaluated with Student's $t$ test and are given as mean \pm $\mathrm{SD}$. The level of significance was set at $5 \%$.

\section{Astrocyte cultures}

Isolation, culturing, and dye injections of astrocytes as well as growth measurement were performed as described previously (Naus et al., 1997). Astrocyte cultures were obtained from newborn mice. For each genotype, 30 cells from two different astrocyte cultures were injected with Lucifer yellow (LY), and the number of dye-filled neighboring cells was counted. For growth measurements, cells were plated at an initial density of $4 \times 10^{5}$ cells per $35 \mathrm{~mm}$ dish after $6 \mathrm{~d}$ in culture, and cells were counted at different time points after plating. For each successive time point, one dish of a single astrocyte preparation was analyzed. Data of five $\left(\mathrm{Cx} 43^{\mathrm{fl} / \mathrm{fl}}\right)$ to six $\left(\mathrm{Cx} 43^{\mathrm{fl} / \mathrm{fl}}\right.$, hGFAP-cre $)$ astrocyte preparations were pooled. Statistical significance was determined using the Student's $t$ test. Significance level was set at $5 \%$.

\section{Measurement of dye coupling in hippocampal slices}

Animals and slice preparation. Two $\mathrm{Cx} 43^{\mathrm{f} / \mathrm{fl}}$ and two $\mathrm{Cx} 43^{\mathrm{f} / \mathrm{fl}}, \mathrm{hGFAP}-\mathrm{Cre}$ mice aged between 52 and $64 \mathrm{~d}$ were used. Hippocampal slices $(300 \mu \mathrm{m})$ were prepared as described previously (Steinhäuser et al., 1992). For patchclamp analysis, in situ slices were placed in a perfusing chamber installed on the stage of a microscope (Axioskop, Zeiss, Oberkochen, Germany).

Solutions and electrodes. The chamber was perfused continually with artificial CSF (ACSF) containing (in mM): $126 \mathrm{NaCl}, 3 \mathrm{KCl}, 2 \mathrm{MgSO}_{4}, 2$ $\mathrm{CaCl}_{2}, 10$ glucose, $1.25 \mathrm{NaH}_{2} \mathrm{PO}_{4}, 26 \mathrm{NaHCO}_{3}$, equilibrated with $95 \%$ $\mathrm{O}_{2}$ and $5 \% \mathrm{CO}_{2}$ to a $\mathrm{pH}$ of 7.4 at room temperature. The pipette solution was composed of (in mM): $130 \mathrm{~K}$-gluconate, $1 \mathrm{MgCl}_{2}$, 3 ATP, 20 HEPES, 10 mm EGTA, 0.5\% biocytin (Sigma), pH 7.2. Recording pipettes were fabricated from borosilicate capillaries (Hilgenberg, Malsfeld, Germany) and had resistances ranging from 3 to $5 \mathrm{M} \Omega$.

Filling of astrocytes with biocytin and electrophysiological recordings. Astrocytes in the stratum radiatum of the CAl hippocampal region were selected using water immersion optics and were filled via the patch pipette during whole-cell recordings (20 min) (Kressin et al., 1995). Only cells with stable input resistance over the $20 \mathrm{~min}$ period were considered for data analysis. During recording, the membrane was continuously dehyperpolarized and hyperpolarized between -160 and $+70 \mathrm{mV}$. Current signals were amplified (EPC 9/2, HEKA Elektronik, Lambrecht, Germany), filtered (10 kHz), sampled (30 kHz), and monitored with TIDA software (HEKA). Capacitance and series resistance compensation (65$75 \%$ ) were used to improve voltage-clamp control.

Tissue processing and staining for biocytin. Cryosectioning $(60 \mu \mathrm{m})$ and biocytin detection were performed as described by D'Ambrosio et al. (1998) with few modifications. Tissue was fixed in 4\% PFA in $0.1 \mathrm{~m} \mathrm{PBS}$ and incubated with Elite ABC kit (Vector, Burlingame, CA) for $48 \mathrm{hr}$. The $\mathrm{DAB}$ reaction took exactly $15 \mathrm{~min}$, and the tissue was embedded in mounting medium (Sigma).

Evaluation of dye coupling and image acquisition. Biocytin-filled cells were counted on the $60 \mu \mathrm{m}$ sections obtained from the respective 300 $\mu \mathrm{m}$ slice $(40 \times$ lens; Zeiss Axiophot equipped with differential interference contrast optics). Images were taken with a digital camera and appropriate software (Diagnostic Instruments). Significant differences between data were evaluated with Student's $t$ test and are given as mean \pm SD. The level of significance was set at $5 \%$.

\section{Measurement of spreading depression in brain slices}

Animals and slice preparation. Preparation was performed as described previously (Dreier and Heinemann, 1991). Horizontally sectioned (400 $\mu \mathrm{m}$ ) hippocampal slices of eight $\mathrm{Cx} 43^{\mathrm{fl} /+}$, four $\mathrm{Cx} 43^{\mathrm{fl} /-}$, and six $\mathrm{Cx} 43^{\mathrm{fl} /-}$, hGFAP-cre mice were obtained. The slices contained parts of the temporal neocortex, the entorhinal cortex, the dentate gyrus, hippocampal areas CA1-4, and the subicular complex. Slices were placed on transparent 
membranes ( $0.4 \mu \mathrm{m}$ Millicell culture plate inserts; Millipore) in interface recording chambers where recordings were performed.

Solutions. Slices were perfused continuously $(1.5-2 \mathrm{ml} / \mathrm{min})$ with prewarmed $\left(34.5^{\circ} \mathrm{C}\right)$ ACSF that contained (in $\mathrm{mm}$ ): $129 \mathrm{NaCl}, 3 \mathrm{KCl}, 1.25$ $\mathrm{NaH}_{2} \mathrm{PO}_{4}, 10$ glucose, $1.8 \mathrm{MgSO}_{4}, 1.6 \mathrm{CaCl}_{2}$, and $21 \mathrm{NaHCO}_{3}$, oxygenated with $95 \% \mathrm{O}_{2}$ and $5 \% \mathrm{CO}_{2}, \mathrm{pH}$ 7.4. The viability of slices was tested by recording stimulus-induced fast and slow field potentials after $>1 \mathrm{hr}$ of recovery.

Electrographic recordings. Two ion-sensitive recording electrodes [prepared and tested as described by Lux and Neher (1973)] were used to record extracellular field potentials and $\mathrm{K}^{+}$concentration changes within the stratum (st.) pyramidale of area CA1 and thus monitor electrographically the spread of SD in CA1. One proximal electrode was positioned into st. pyramidale of CA1 near the border to CA2 and one distal electrode into st. pyramidale of CA1 near the border to the subiculum. Maximally three SD waves in succession were induced by brief pressure injection of $1 \mathrm{M} \mathrm{KCl}$ through a glass capillary (tip diameter 3-5 $\mu \mathrm{m})$ into the st. radiatum of area CA1 near the proximal recording electrode. A fast field potential was always induced before each SD induction to ascertain that the stimulus-induced field potential had fully recovered. The minimum interval between SDs was $30 \mathrm{~min} . \mathrm{K}^{+}$peak amplitudes were measured in millivolts and transformed into micromolar changes of concentration by use of the Nernst equation. Recordings were performed using pClamp 6.0.3 software (Axon Instruments, Foster City, CA) with sampling rates of $10 \mathrm{~Hz}$. The results were compared with the results of optical imaging.

Optical imaging was performed simultaneously to the electrographic recordings by a method described previously by Buchheim et al. (2000). In short, slices were homogeneously transilluminated from below using unfiltered light. Transmitted light was detected by an eight-bit CCD camera (Sanyo, Japan). Video signals were digitized and analyzed using a frame-grabber board (DT2855, Data Translation, Marlboro, MA) and in-house software. To examine alterations of the intrinsic optical signal (IOS) after SD induction, all subsequent images were subtracted from control images. These subtracted images disclosed areas in the slice where light transmission had changed. Light transmission changes and propagation velocity of the IOS were analyzed. Light transmission changes were determined in the region between both recording electrodes. The SD propagation velocity was determined by marking the wave front of transmission changes ( $\geq 10 \%$ of maximal transmission changes) in subsequent images and dividing the resulting distances by the time intervals between the individual images. Propagation velocities of SD in st. oriens/ pyramidale and st. radiatum were compared. Only those experiments in which SD reached the distal electrode were analyzed.

All data are expressed as mean values \pm SEM with $n$ being the number of measurements. Statistical significance was determined using the Student's $t$ test. Significance level was set at $5 \%$.

\section{Behavioral analysis}

The open field apparatus was a rectangular chamber $(30 \times 30 \times 35 \mathrm{~cm})$ made of gray polyvinylchloride. It was divided into nine equally sized small squares $(10 \times 10 \mathrm{~cm})$ by six virtual lines. A video camera, a loudspeaker providing masking noise, and a $25 \mathrm{~W}$ red light bulb placed 250 $\mathrm{cm}$ above the maze (illumination density at the center of the maze, 0.3 Lux) were positioned above its center. Mice were placed in the center and observed for $5 \mathrm{~min}$. After each trial, the apparatus was swept out with water containing $0.1 \%$ acetic acid. The behavioral parameters registered were as follows: (1) locomotion: the number of line crossings; (2) rearing: the number of times an animal was standing on its hind legs with forelegs in the air or against the wall; and (3) grooming: the duration of grooming behavior. Statistical analysis was performed using Student's two-tailed $t$ test, with the level of significance set at 5\%.

\section{Results}

Indicating $h G F A P$-cre-mediated loss of $\mathrm{Cx} 43$ expression by lac $Z$ activation

hGFAP-cre activity, which leads to loss of Cx43 expression, can be monitored by $\mathrm{X}-\mathrm{Gal}$ staining, as outlined schematically in Figure $1, A$ and $B$. Before $h G F A P$-cre-mediated deletion of floxed DNA

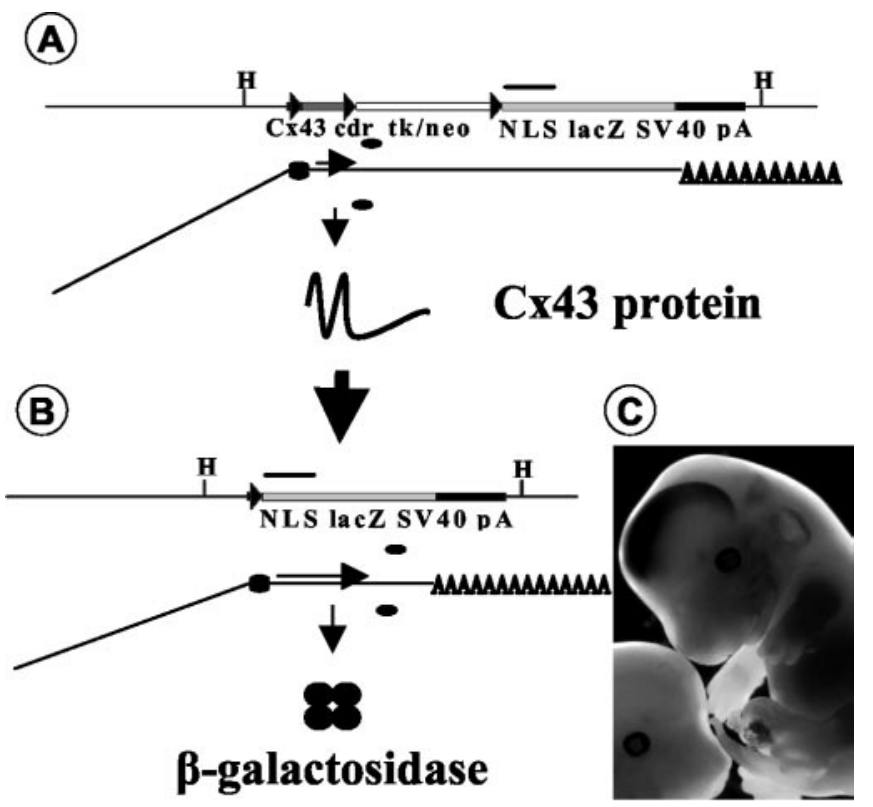

Figure 1. Concept of lacZ activation on $C x 43$ deletion. Cre-mediated deletion of floxed DNA at the $C x 43$ locus leads to lac $Z$ expression in cells that show $C x 43$ gene activity. $A, C x 43$ genomic DNA and mRNA and protein expression of the $C \times 43^{f l}$ allele. Top row, Genomic DNA. Thin line, genomic DNA; black boxes, noncoding part of C $x 43$ exon 2; dark gray box, Cx43-coding region ( $C x 43 \mathrm{cdr}$ ); white box, selection marker DNA in reverse orientation to $C x 43$ and lacZ; light gray box, lacZ reporter gene with nuclear localization signal (NLS) and polyadenylation signal (SV40 pA); triangles, loxP sites; bar, $1 \mathrm{~kb} ; \mathrm{H}$, Hindlll; $c d r$, coding region; $t k$, Herpes simplex virus thymidine-kinase; neo, neomycin-phosphotransferase. Bottom row, mRNA processing. Horizontal line, Exonic RNA; inclined line, intronic RNA; $A A A A$, polyadenylated mRNA tail; ellipses, ribosomes. Horizontal arrow delineates translated mRNA. Small vertical arrow delineates translation process. Large vertical arrow delineates cre-mediated deletion. $B,(x 43$ genomic DNA and mRNA and protein expression of the $C \times 43^{\text {del }}$ allele. For explanations, see $A$. Circles indicate $\beta$-galactosidase peptides. C, X-Gal-stained $13.5 \mathrm{dpc}$ embryos; LacZ expression in the developing brain of a $\mathrm{C} \times 43^{\mathrm{fl} /+}$, hGFAP-cre embryo and nonstained $\mathrm{C} \times 43^{\mathrm{fl} /+}$ control embryo.

(Fig. $1 A$ ), a $C x 43^{f l}$ mRNA containing two open reading frames is generated. Only the $5^{\prime}$ open reading frame, coding for the Cx43 protein, is translated, whereas the second open reading frame, in the same orientation and encoding $\beta$-galactosidase, is not. On cre-mediated deletion of floxed DNA (Fig. $1 B$ ), the $\beta$-galactosidase open reading frame is translated. In this case, expression of $\beta$-galactosidase is under the control of the regulatory elements of the $C \times 43$ gene, and a positive finding for $\beta$-galactosidase implies a corresponding loss of $\mathrm{Cx} 43$ expression. The onset of X-Gal staining in mice expressing the $h G F A P$-cre transgene and the $C \times 43^{f l}$ allele was observed at 12.5 days post coitum (dpc) (data not shown). Full expression, which occurred in developing brain and spinal cord, was achieved at $13.5 \mathrm{dpc}$ (Fig. 1C).

\section{Extent of $h G F A P$-cre-mediated deletion and loss of Cx43 expression}

As depicted schematically in Figure 1, $A$ and $B$, we determined the extent of $\mathrm{Cx} 43$ inactivation at the DNA level by Southern blot hybridization (Fig. 2A). In adult brain as well as in astrocyte cultures, we detected nearly complete Cre/loxP-mediated conversion of the $C x 43^{f l}$ allele to the $C x 43^{\text {del }}$ allele.

At the protein level, we determined the loss of $\mathrm{Cx} 43$ expression in astrocyte cultures of different age and in forebrain and cerebellum of adult mice (Fig. $2 B$, Table 1 ). We found nearly complete loss of $\mathrm{Cx} 43$ protein in all cases. As reported for heart (Theis et al., 2001), the mRNA level (data not shown) and the protein expression of the floxed allele were decreased by $50 \%$ 
(A) 1

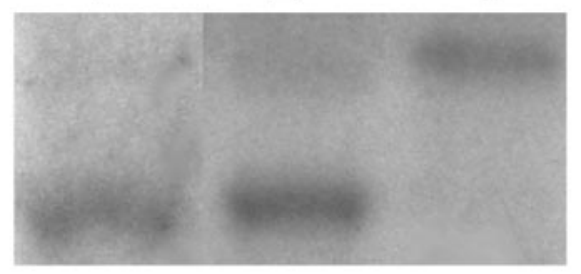

$11.8 \mathrm{~kb}$

(B)
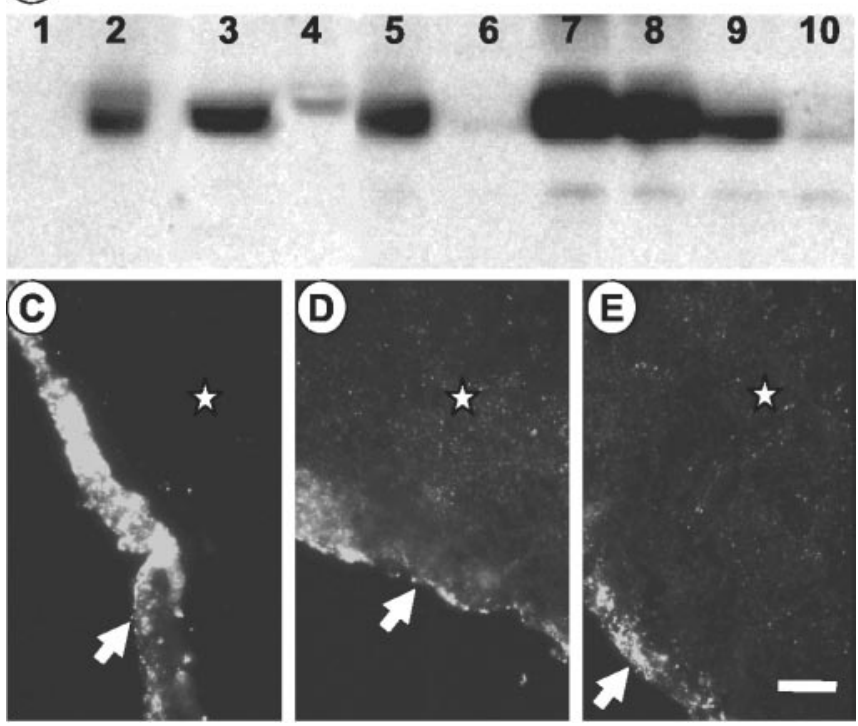

Figure 2. Extent of $h G F A P$-cre-mediated deletion and loss of expression. $A$, Southern blot analysis. Hindlll-digested genomic DNA was hybridized to a probe complementary to the lacZ reporter gene associated with the $C \times 43^{f l}$ and the $C x 43^{\text {del }}$ allele, generating 11.8 and $7.7 \mathrm{~kb}$ fragments, respectively. Comparison of the band intensity allows determination of the extent of hGFAP-cre-mediated conversion of the $C \times 43^{f l}$ allele to the $C \times 43^{\text {del }}$ allele. Lane 1, Adult $\mathrm{Cx} 43^{\mathrm{fl} /+}$, hGFAP-cre mouse cerebellum. Lanes 2, 3, 0ne-week-old astrocyte cultures of newborn mice: $\mathrm{Cx}_{3} 3^{\mathrm{fl} /+}$, hGFAP-cre (lane 2); $\mathrm{Cx} 43^{\mathrm{fl} /+}$ (Iane 3). B, Immunoblot analysis with antibodies directed to $C x 43$, which specifically detected a $43 \mathrm{kDa}$ protein. Lane 1, HeLa wild type. Lane 2, HeLa cell clone transfected with a Cx43 expression vector. Lanes 3, 4, Three-week-old astrocyte cultures: $\mathrm{Cx} 43^{\mathrm{fl} / \mathrm{fl}}$ (lane 3); (x43 ${ }^{\mathrm{fl} / \mathrm{fl}}$, hGFAP-cre (lane 4). Lanes 5, 6, Six-week-old astrocyte cultures: $\mathrm{Cx} 43^{\mathrm{fl} / f \mathrm{l}}\left(\right.$ lane 5); $\mathrm{Cx} 43^{\mathrm{fl} / \mathrm{fl}}, \mathrm{hGFAP}$-cre (lane 6). Lanes 7-10, Adult cerebellum: $\mathrm{Cx} 43^{+/+}$(lane $7) ;\left(\mathrm{C} 43^{+1-}\right.$ (lane 8); $\left(\mathrm{x} 43^{\mathrm{fl} /-}\right.$ (lane 9$) ;\left(\mathrm{C} 43^{\mathrm{fl} /-}\right.$, hGFAP-cre (lane 10). (-E, Demonstration of hGFAP-cre-mediated loss of $\mathrm{C} \times 43$ expression in cerebellum by immunofluorescence analysis of horizontal cryosections. C, Cx43 ${ }^{\mathrm{fl} /-}$, hGFAP-cre, TIE2-cre. D, Cx43 ${ }^{\mathrm{fl} /-}$, TIE2-cre. E, Cx43 ${ }^{\mathrm{fl} / \mathrm{fl}}$. Arrow indicates leptomeningeal layer; asterisk indicates molecular layer. Scale bar, $24 \mu \mathrm{m}$.

compared with a wild-type allele in brain (Fig. 2 B, lanes 8 and 9). $h G F A P$-cre-mediated deletion essentially abolished $\mathrm{Cx} 43$ protein expression in the brain, as shown for cerebellum (Fig. 2B, lane 10). Because nonastrocytic cells also contribute to the cerebellar protein lysate, the remaining faint signal is likely caused by leptomeningeal and endothelial expression of $\mathrm{Cx} 43$. All data are quantitatively summarized in Table 1.

To assess which cell type contributes to residual immunoreactivity in brain immunoblots, we performed immunofluorescence studies on mice with dual astrocyte-specific and endothelial-cell specific, TIE2-cre-mediated deletion. In the molecular layer of the cerebellum (Fig. 2C) of $\mathrm{Cx} 43^{\mathrm{fl} /-}$, hGFAP-cre, TIE2-cre mice, no $\mathrm{Cx} 43$ immunoreactivity was detected. The $\mathrm{Cx} 43$ immunoreactivity of $\mathrm{Cx} 43^{\mathrm{fl} /-}$, TIE2-cre mice (Fig. $\left.2 \mathrm{D}\right) \mathrm{did}$ not differ from that of $\mathrm{Cx} 43^{\mathrm{fl} / \mathrm{fl}}$ mice (Fig. $2 \mathrm{E}$ ). This indicates that endothelial expression of $\mathrm{Cx} 43$ abolished by TIE2-cre-mediated deletion did not contribute substantially to the total Cx43 expression in the adult brain as opposed to astrocytic expression. The Cx43 immunoreactivity in leptomeningeal cells was not affected
Table 1. Extent of GFAP-cre-mediated deletion and loss of expression

\begin{tabular}{|c|c|c|}
\hline Specimen & $\begin{array}{l}\text { Type of } \\
\text { analysis }\end{array}$ & Deletion or loss of expression ${ }^{a}$ \\
\hline Astrocyte culture, 4 weeks, fl/fl; cre & IF & $90 \%$ loss of expression ( $94 \%$ of GFAP ${ }^{+}$cells) \\
\hline Astrocyte culture, 6 weeks, fl/fl; cre & IF & $90 \%$ loss of expression ( $94 \%$ of GFAP ${ }^{+}$cells) \\
\hline Astrocyte culture, 3 weeks, fl/fl; cre & WB & $91 \%$ loss of expression \\
\hline Astrocyte culture, 6 weeks, fl/fl; cre & WB & $100 \%$ loss of expression \\
\hline Cerebellum, adult, $\mathrm{fl} /-$; cre & WB & $100 \%$ loss of expression \\
\hline Forebrain, adult, fl/-; cre & WB & $90 \%$ loss of expression \\
\hline Cerebellum, adult, $\mathrm{fl} /+$; cre & SB & $93 \%$ deletion \\
\hline Forebrain, adult, fl/ + ; cre & SB & 93\% deletion \\
\hline Astrocyte culture, 6 days, $\mathrm{fl} /+$; cre & SB & $89 \%$ deletion \\
\hline
\end{tabular}

IF, Immunofluorescence; WB, immunoblot; SB, Southern blot.

${ }^{a}$ To determine hGFAP-cre-mediated loss of $\mathrm{Cx} 43$ expression, the expression of $\mathrm{Cx} 43^{\mathrm{fl} / \mathrm{fl}}$, hGFAP-cre, and $\mathrm{Cx} 43^{\mathrm{fl} /-}$ hGFAP-cre specimens was always compared with the expression of $\mathrm{C} \times 43^{\mathrm{fl} / \mathrm{fl}}$ and $\mathrm{C} \times 43^{\mathrm{ff} /}-$ specimens, respectively. The extent of deletion was assessed densitometrically as described previously (Betz et al., 1996) by the following equation: band intensity of $\mathrm{C} \times 43^{\text {del }}$ fragment/(band intensities of $\mathrm{C} \times 43^{\text {del }}$ fragment $+\left(\mathrm{C} 43^{\mathrm{fl}}\right.$ fragment) $\times 100$. All data are mean values from duplicate experiments (two animals).

by $h G F A P$-cre-mediated deletion, in accordance with the expression pattern of the $h G F A P$-cre transgene, which excluded leptomeningeal cells (Fig. $3 N$ ).

\section{Cell-type specificity of $h G F A P$-cre-mediated lac $Z$ activation}

The activity of the $h G F A P$-cre transgene used in this study was not confined to astrocytes and ependymal cells, but occurred in neurons as well (Zhuo et al., 2001). To determine the cell-type specificity of $h G F A P$-cre-mediated inactivation of $\mathrm{Cx} 43$, we performed double-immunofluorescence analysis for $\beta$-galactosidase and the astrocytic marker protein GFAP (Fig. $3 A, B$ ). Although the subcellular localization of both proteins is not identical, frequent overlap of cytoplasmic GFAP and nuclear $\beta$-galactosidase was found in hippocampal cryosections of $\mathrm{C} \times 43^{\mathrm{fl} /+}$, hGFAP-cre mice (Fig. $3 A$ ). The pattern was indistinguishable from cryosections of $\mathrm{Cx} 43^{\mathrm{del} /+}$ mice (Fig. $3 C$ ). For both genotypes, no overlap was found in double-immunofluorescence analysis for $\beta$-galactosidase and NeuN, a panneuronal marker protein that is essentially localized to the nucleus (Fig. $3 B, D$ ). Similar results were obtained in the cerebellum (data not shown).

X-Gal staining of brain cryosections from mice with different cre-mediated deletions confirmed the predominantly astrocytic expression of $\mathrm{Cx} 43$ in brain: lac $Z$ expression in the cortex of $\mathrm{Cx} 43^{\mathrm{del} /+}$ mice, with general deletion of the $C x 43^{f l}$ allele (Fig. $3 E$ ), is very similar to lac $Z$ expression in $\mathrm{Cx} 43^{\mathrm{fl} /+}$, hGFAP-cre mice (Fig. $3 F$ ). The same was observed in cerebellar cryosections with the exception that $\mathrm{Cx} 43^{\mathrm{fl} /+}$, hGFAP-cre mice essentially lack $\beta$-galactosidase activity in leptomeningeal cells and in endothelial cells of the molecular layer (Fig. $3 M, N$ ). TIE2-cre-mediated deletion of $C x 43$ reveals expression of $\mathrm{Cx} 43$ in endothelial cells of the brain microvasculature similar to other organs ( $\mathrm{cf}$. Theis et al., 2001). In contrast to $h G F A P$-cre-mediated deletion, endothelial deletion led to a sparse lac $Z$ expression pattern, indicating that $\mathrm{Cx} 43$ is not prominently expressed in brain endothelial cells (Fig. $3 G$ ). In the hippocampus, the relative abundance of $\mathrm{Cx} 43$ expression in the respective cell types was very similar to cortex (Fig. 3I-K). Endothelial lac $Z$ expression with a characteristic streak-like arrangement of stained nuclei occurred in mice with general deletion and TIE2-cre-mediated deletion and was most easily detected in the molecular layer of the cerebellum (Fig. $3 \mathrm{M}, \mathrm{O})$. This pattern was never observed in mice with hGFAPcre-mediated deletion (Fig. $3 N$ ). In the ventricles, TIE2-cremediated deletion led to lac $Z$ staining in the choroid plexus, most likely in endothelial cells (Fig. $3 L$ ), whereas $h G F A P$-cre-mediated 

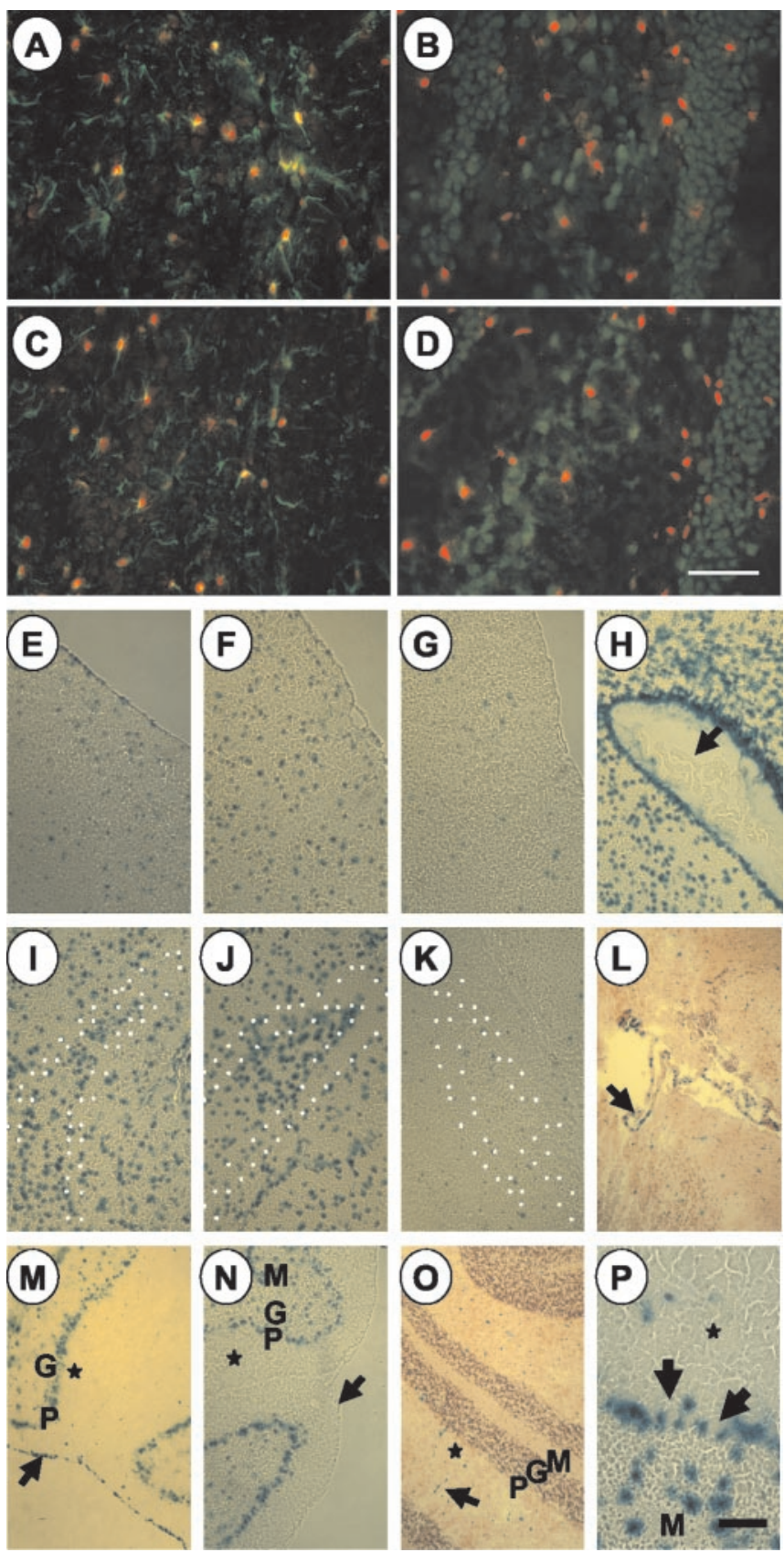

Figure 3. Cell-type specificity of $h G F A P$-cre-mediated $C \times 43$ inactivation monitored by lac expression. $A-D$, Double-immunofluorescence analysis on hippocampal cryosections of $C \times 43^{\mathrm{fl} /+}$, hGFAP-cre mice $(A, B)$ and $C \times 43^{\mathrm{del} /+}$ mice $(C, D)$ using antibodies directed to $\beta$-galactosidase (red) and $\operatorname{GFAP}(A, C$, green) or $\operatorname{NeuN}(B, D$, green). Coexpression of $\beta$-galactosidase with GFAP $(A)$ but not with NeuN $(B)$ occurs in $C \times 43^{\mathrm{fl} /+}$, hGFAP-cre mice indistinguishable from that in $C \times 43^{\text {del } /+}$ mice ( $C$ and $D$, respectively). Scale bar (shown in $\left.D\right): 50$ $\mu \mathrm{m} . E-P, X-G a l$ staining of brain cryosections from mice with general $\left(E, I, M, C \times 43^{\mathrm{del} /+}\right)$, astrocyte-specific $\left(F, J, N, H, C \times 43^{\mathrm{fl} / \text { - }}\right.$, hGFAP-cre), endothelial cell-specific deletion of the $C \times 43^{f l}$ allele $\left(G, K, 0, L, C \times 43^{\mathrm{fl} /--}\right.$, TIE2-cre), and multiple cre-transgenic mice $\left(P, C \times 43^{\mathrm{fl} / \text { - }}\right.$, hGFAP-cre, TIE2-cre). Scale bar (shown in P): E-0, $140 \mu \mathrm{m} ; P, 24 \mu \mathrm{m}$. E-G, Cortex. I-K, Hippocampus. White dots demarcate granule cells of the dentate gyrus and pyramidal cells. $H, L$, Ventricles. Arrow indicates choroid plexus. $M-P$, Cerebellum. Asterisk indicates molecular layer. $P$, Purkinje cell layer; $G$, granule cell layer; $M$, white matter. Arrows in $M$ and $N$ indicate leptomeningeal cell layer. Arrow in 0 indicates streak-like arrangement of lacZ-expressing cells indicative of blood vessels. Arrows in P indicate nonexpressing Purkinje cell bodies. deletion led to a strong expression in ependymal cells lining the ventricles and subependymal cells, but not in the choroid plexus (Fig. $3 H$ ). Ventricles of $\mathrm{Cx} 43^{\mathrm{del} /+}$ mice showed lac $Z$ expression that was essentially a summation of the endothelial and the astrocytic-ependymal subcompartments (data not shown). In the cerebellum, the lac $Z$ expression of doubly cre-transgenic $\mathrm{Cx} 43^{\mathrm{fl} /-}$, hGFAP-cre, TIE2-cre mice was also identical to the lacZ expression pattern of $\mathrm{Cx} 43^{\mathrm{del} / /+}$ mice with the exception of leptomeningeal cells (Fig. 3P) (and data not shown). Thus, on the basis of lacZ expression studies, the main Cx43-expressing cell types besides endothelial and leptomeningeal cells are astrocytes.

Dual $h$ GFAP-cre, TIE2-cre-mediated deletion led to lacZ expression in Bergmann glia cells of the Purkinje cell layer and in the granular layer as well as the white matter tracts but not in Purkinje cells, as shown in Figure $3 P$. Because $\mathrm{Cx} 43^{\mathrm{del} /+}$ mice also do not express lac $Z$ in this cell type (data not shown), the $C \times 43$ gene appears transcriptionally inactive in Purkinje cells.

\section{Astrocyte cultures from mice with $h G F A P$-cre-mediated deletion of $C x 43$ behave like $\mathrm{Cx} 43^{-/-}$astrocytes}

We attempted to reproduce the reported phenotypical alterations in astrocyte cultures from Cx $43^{-1-}$ mice (Naus et al., 1997; Dermietzel et al., 2000; Rouach et al., 2000) in mice with $h$ GFAP-cremediated inactivation of $\mathrm{Cx} 43$ (Fig. 4). In 4-week-old cultures, we have previously observed a $90 \%$ decrease of $\mathrm{Cx} 43$-expressing cells and a 90\% decrease in LY coupling (Contreras et al., 2002). In contrast to cultures from $\mathrm{Cx} 43^{-1-}$ mice, nonastrocytic contaminating cells in cultures with $h G F A P$-cre-mediated deletion might still express $\mathrm{Cx} 43$. Therefore, we performed doubleimmunofluorescence analysis for GFAP and Cx43 to determine the astrocyte-specific loss of $\mathrm{Cx} 43$ expression in culture and found a 94\% decrease of Cx43-expressing GFAP-positive cells (Table 1). Given a purity of $95 \%$ astrocytic cells as determined by GFAP antibody staining (data not shown), 6\% of GFAPexpressing cells did not undergo $\mathrm{cre}$-mediated deletion at 4 weeks of culture. Also, 5\% of GFAP-negative cells remained in the cultures as potentially $\mathrm{Cx} 43$ expressing cells. Thus, part of the observed residual coupling is attributable to incomplete cre activity, whereas another part is attributable to a contamination of the cultures with nonastrocytic cells.

In dye transfer studies with Lucifer yellow, we found a striking decrease in the probability and the extent of intercellular coupling (Fig. $4 A, B$ ). In $\mathrm{Cx} 43^{\mathrm{fl} / \mathrm{fl}}$ cultures, the majority of the injected cells (22 of 30) transferred dye to more than six neighboring cells (Fig. 4C). Only a minority of the injected cells from $\mathrm{Cx} 43^{\mathrm{f} / \mathrm{fl}}$, hGFAP-cre cultures ( 4 of 30 ) showed dye coupling that then never spread to more than six neighboring cells. Most of the cells (26 of 30) did not couple at all (Fig. 4C).

We also observed a decrease in growth and saturation density in $\mathrm{Cx} 43^{\mathrm{fl} / \mathrm{fl}}$, hGFAP-cre cultures (Fig. $4 D$ ), similar to observations on $\mathrm{Cx} 43^{-1-}$ astrocytes (Naus et al., 1997; Dermietzel et al., 2000). The difference between $\mathrm{Cx} 43^{\mathrm{fl} / \mathrm{fl}}$ cultures and $\mathrm{Cx} 43^{\mathrm{fl} / \mathrm{fl}}$, hGFAP-cre cultures in cell number was significant at all time points later than $24 \mathrm{hr}$ after plating (corresponding to $7 \mathrm{~d}$ in culture) (Fig. $4 D$ ). The difference in growth was caused mainly by a delayed onset of growth after plating (Fig. $4 D$ ).

\section{Investigation of viability, neurodegeneration, compensation} by other connexins, and astrocyte growth in vivo

Mice lacking Cx43 in astrocytes and ependymal cells were viable and fertile and did not display any obvious phenotypic abnormality, such as handling-induced seizures (data not shown). Histological analysis of adult mice lacking $\mathrm{Cx} 43$ in astrocytes with 

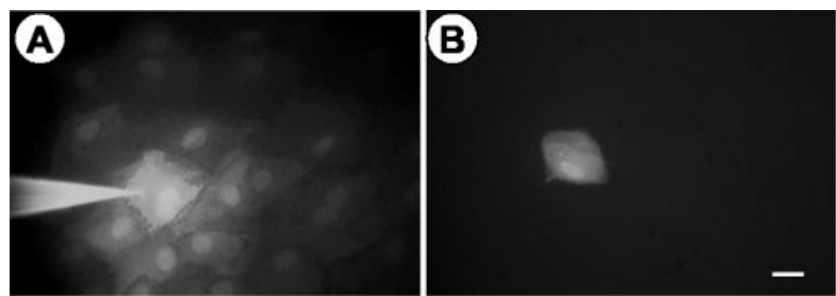

(C)

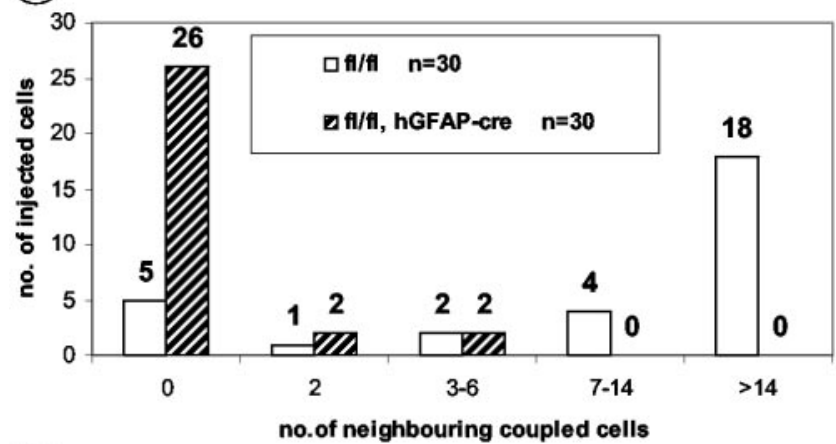

(D)

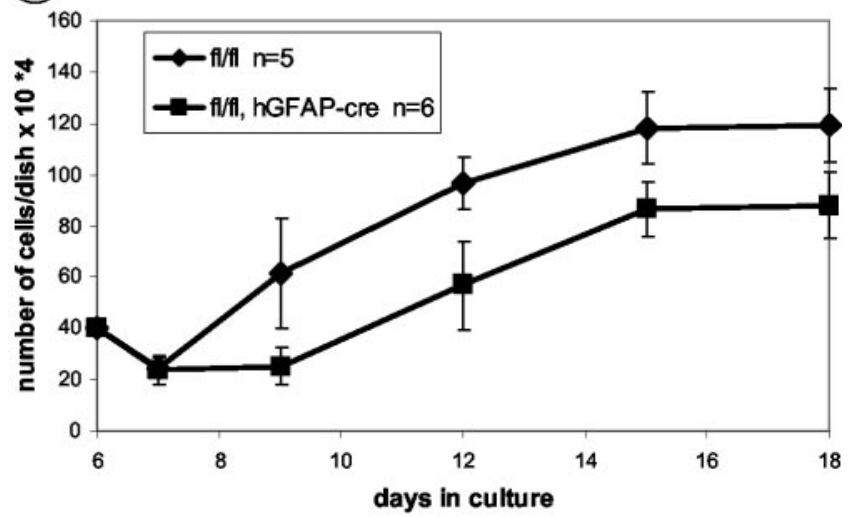

Figure 4. Phenotypical characterization of astrocyte cultures with $h$ GFAP-cre-mediated inactivation of $\mathrm{Cx} 43 . A, B$, Cre-mediated loss of intercellular Lucifer yellow transfer. $A, C x 43^{\mathrm{fl} / \mathrm{fl}} . B$, $\mathrm{C} \times 43^{\mathrm{f} / / \mathrm{fl}}$, hGFAP-cre. Scale bar, $20 \mu \mathrm{m}$. C, Extent of $\mathrm{LY}$ coupling in 4-week-old astrocyte cultures. For each genotype, 30 cells were injected, and dye-stained neighboring cells were counted. White bars represent $\mathrm{C} \times 43^{\mathrm{f} / / \mathrm{fl}}$. Shaded bars represent $\mathrm{C} \times 43^{\mathrm{f} / / \mathrm{fl}}$, hGFAP-cre. D, Delayed onset of growth and decreased saturation density in astrocyte cultures lacking $C \times 43$. At all time points beginning later than $24 \mathrm{hr}$ after plating ( $7 \mathrm{~d}$ of culture), the number of $\mathrm{C} \times 43^{\mathrm{f} / \mathrm{fl}}$, hGFAP-cre cells was significantly lower than the number of $\mathrm{C} x 43^{\mathrm{fl} / \mathrm{fl}}$ cells. Data are pooled from five $\left(\mathrm{C} \times 43^{\mathrm{fl} / \mathrm{fl}}\right)$ to $\operatorname{six}\left(C \times 43^{f l / f l}\right.$, hGFAP-cre) experiments. 10*4: 10,000.

hematoxylin and eosin-stained and Nissl-stained coronal sections did not reveal any neurodegeneration in cortex, hippocampus, and cerebellum (data not shown). Also, there was no obvious sign of astrogliosis as assessed by GFAP antibody staining, the presence of which might have indicated subtle pathology in brains of mice lacking Cx43 in astrocytes (data not shown).

Cx43 in astrocyte cultures seemed to have an enhancing effect on growth (Fig. 4D). Therefore, we quantitatively determined astrocyte number in the adult brain. We chose the stratum radiatum of the hippocampal CA1 region, in which we performed electrophysiological and dye-coupling experiments (see below). The number of GFAP-positive cells in a microscopic field of $\mathrm{Cx} 43^{\mathrm{fl} / \mathrm{fl}}$ sections ( $32 \pm 5 ; 76$ measurements; two animals) and of $\mathrm{Cx} 43^{\mathrm{fl} / \mathrm{fl}}$, hGFAP-cre sections ( $32 \pm 4 ; 70$ measurements; two animals) did not differ significantly from each other.

To assess compensatory expression changes of other connexin

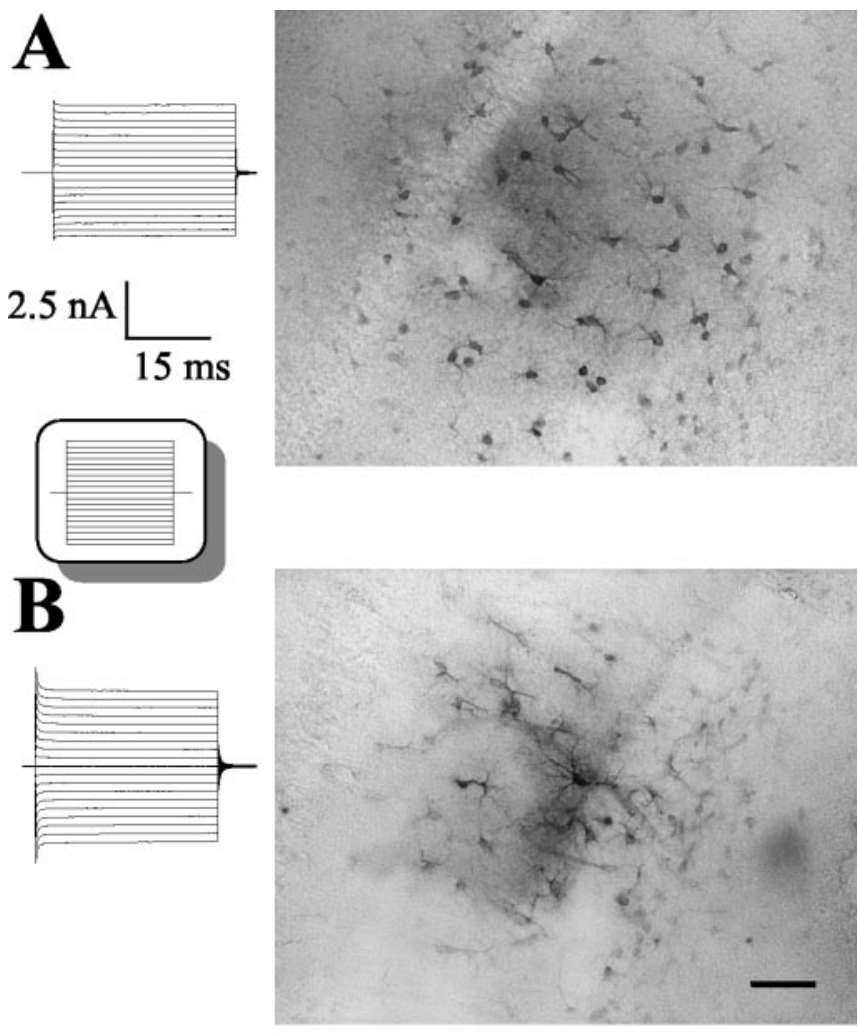

C

$\mathrm{Cx} 26$

$\mathrm{Cx} 30$

$\mathrm{Cx} 43$

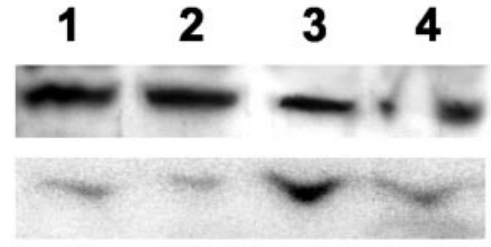

$\mathrm{Cx} 45$
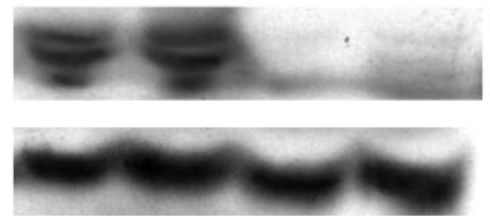

Figure 5. Reduced dye coupling on C $x 43$ deletion in the hippocampus and evaluation of compensatory upregulation of other connexin genes. $A$, Membrane currents of a dye-injected astrocyte in a $\mathrm{C} 43^{\mathrm{fl} / \mathrm{fl}}$ slice were activated applying dehyperpolarizing and hyperpolarizing voltage steps between -160 and $+20 \mathrm{mV}$ (inset, left panel). The right panel displays the extent of biocytin coupling to the cell shown in $A$ ( $60 \mu \mathrm{m}$ section). $B$, Current pattern of an astrocyte in a $\mathrm{C} \times 43^{\mathrm{fl} / \mathrm{fl}} \mathrm{hGFAP}$-cre mouse (left) and extent of biocytin coupling to that cell (right). The cre-mediated deletion of $C x 43$ leads to a reduction of $\sim 50 \%$ in astrocytic coupling. Scale bar, $50 \mu \mathrm{m}$. C, Immunoblot analysis of brain lysates with antibodies directed to $\mathrm{Cx} 26, \mathrm{C} \times 30$, $\mathrm{Cx} 43$, and $\mathrm{Cx} 45$. Lane 1, Cx43 $3^{\mathrm{fl} / \mathrm{fl}}$, cortex. Lane 2, Cx43 $3^{\mathrm{fl} / \mathrm{fl}}$, cerebellum. Lane 3, Cx43 ${ }^{\mathrm{f} / \mathrm{fl}}$, hGFAPcre, cortex. Lane 4, Cx43 $3^{\mathrm{flfl}}$, hGFAP-cre, cerebellum. Upregulation of $\mathrm{C} \times 30$ expression is apparent in $\mathrm{Cx} 43^{\mathrm{fl} / \mathrm{fl}}, \mathrm{hGFAP}$-cre cortex.

genes, we performed immunoblot and immunofluorescence analysis for $\mathrm{Cx} 26, \mathrm{Cx} 30, \mathrm{Cx} 40$, and $\mathrm{Cx} 45$ in the brains of adult $\mathrm{Cx} 43^{\mathrm{fl} / \mathrm{fl}}$, hGFAP-cre mice. Immunofluorescence analysis of $\mathrm{Cx} 43^{\mathrm{fl} / \mathrm{fl}}$, hGFAP-cre mice revealed no prominent increase in expression of the four mentioned connexin genes in comparison with $\mathrm{Cx} 43^{\mathrm{fl} / \mathrm{fl}}$ mice in any restricted cell population of the CNS (data not shown). The immunoblot data showed no apparent upregulation for Cx26 and Cx45 but did show a twofold in- 
A CA1-st. pyramidale prox. -st. pyramidale dist.

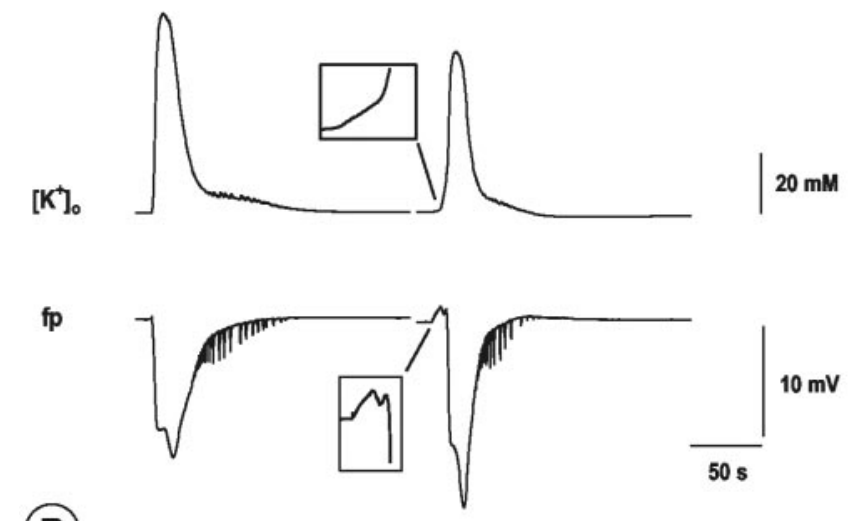

(B)
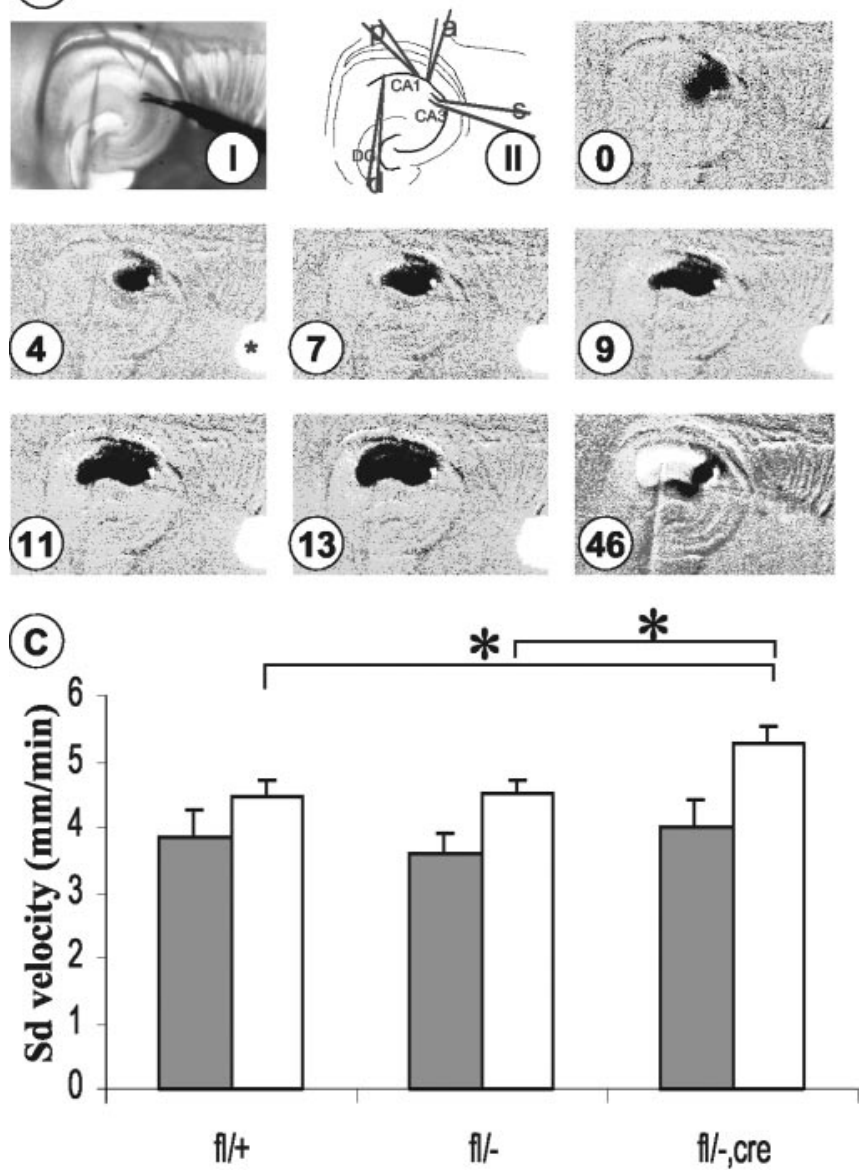

Figure 6. Spreading depression is modulated by $\mathrm{C} \times 43 . A, \mathrm{SD}$ was induced in area $\mathrm{CA} 1$ of a $\mathrm{Cx} 43^{\mathrm{fl} /-}$, hGFAP-cre mouse by pressure injection of $\mathrm{K}^{+}$into st. pyramidale of area $\mathrm{CA} 1$. Changes in $\left[\mathrm{K}^{+}\right]_{0}$ (top row) and field potential (bottom row) were recorded with ion-sensitive microelectrodes (ISMs) placed in the st. pyramidale of proximal (near $\mathrm{K}^{+}$application site) and distal (near the border to subiculum) area CA1. Biphasic negative potential shifts and accompanying increases in $\left[\mathrm{K}^{+}\right]_{0}$ typical for SD could be recorded in CA1. Note the appearance of a positive prepotential and an accompanying slow rising phase of $\left[\mathrm{K}^{+}\right]_{0}$ in distal CA1 (insets). B, Propagation of SD in hippocampal slices of $\mathrm{C} \times 3^{\mathrm{fl} /}$, , hGFAP-cre mouse as revealed by intrinsic optical signal. I, Video picture of hippocampal slice. II, Schematic drawing of the recording and stimulating situation. $p$, Proximal ISM; $d$, distal ISM; $a, \mathrm{~K}^{+}$application electrode; $s$, bipolar stimulation electrode; $D G$, dentate gyrus. $0-46$, Consecutive subtraction images of IOS, numbered with the time after induction (in seconds), showing the situation at the time of $\mathrm{K}^{+}$injection (0) and the propagation of SD along CA1 toward the subiculum (4-46). Asterisks, Negative potential shift at the proximal recording electrode is indicated by a light signal. 46, Recovery of IOS. Note the faster propagation of SD in st. radiatum. C, Comparison of SD propagation velocities. Propagation velocities in st. oriens/pyramidale ( gray bars) of $\mathrm{C} \times 43^{\mathrm{fl} /+}(n=8), \mathrm{Cx}^{\mathrm{fl}}{ }^{\mathrm{fl}-}(n=$ 4), and $\mathrm{C} \times 43^{\mathrm{fl} /}$, , hGFAP-cre $(n=6)$ mice did not differ significantly from each other. By contrast,
Table 2. Parameters of SD in the hippocampus of $\mathrm{Cx} 43^{\mathrm{f} / /+}(n=8), \mathrm{Cx} 43^{\mathrm{fl} /-}$ $(n=4)$, and $\mathrm{C} \times 43^{\mathrm{fl} /}-$, hGFAP-cre $(n=6)$ mice

\begin{tabular}{|c|c|c|c|}
\hline \multirow[b]{2}{*}{ Parameter } & \multicolumn{3}{|l|}{ Genotype } \\
\hline & $\mathrm{Cx} 43^{\mathrm{ff} /+}$ & $\mathrm{C} \times 43^{\mathrm{ff} / /-}$ & $\mathrm{Cx} 43^{\mathrm{ff} /-} ;$ hGFAP-cre \\
\hline $\mathrm{fp}(\mathrm{mV})$ & $-16.8 \pm 1.1(13)$ & $-13.6 \pm 0.5(14)^{*}$ & $-13.8 \pm 0.7(13)^{*}$ \\
\hline$f p(s e c)$ & $58 \pm 15(14)$ & $53 \pm 13(11)$ & $51 \pm 17(11)$ \\
\hline $\mathrm{K}^{+}$rise $(\mathrm{mm})$ & $38.6 \pm 3(13)$ & $38.5 \pm 1.7(14)$ & $42.1 \pm 2.8(13)$ \\
\hline $\begin{array}{l}\mathrm{K}^{+} \text {rise }(\mathrm{sec}) \\
\mathrm{v}(\mathrm{mm} / \mathrm{min}) \text { st. oriens }\end{array}$ & $63 \pm 5(11)$ & $77 \pm 9(10)$ & $61 \pm 3(11)$ \\
\hline $\begin{array}{c}\text { pyramidale } \\
\mathrm{v}(\mathrm{mm} / \mathrm{min}) \text { st. radia- }\end{array}$ & $3.8 \pm 0.4(11)$ & $3.6 \pm 0.3(14)$ & $4 \pm 0.4(13)$ \\
\hline tum & $4.4 \pm 0.3(11)$ & $4.5 \pm 0.2(18)$ & $5.3 \pm 0.2(17)^{* *}$ \\
\hline
\end{tabular}

creased $\mathrm{Cx} 30$ expression in the cortex in two independent experiments (Fig. 5C).

\section{Investigation of brain physiology: decreased astrocytic dye coupling in adult mice with $h G F A P$-cre-mediated Cx43 deletion}

Dye transfer studies in astrocytic cultures from mice with hGFAP-cre-mediated deletion of $C \times 43$ revealed a pronounced reduction of intercellular coupling compared with $\mathrm{Cx} 43^{\mathrm{fl} / \mathrm{ll}} \mathrm{cul}-$ tures; however, changes in growth observed in vitro were not found in vivo, indicating possible compensation by other astrocytic connexins (see above). To confirm that the deletion of $C \times 43$ in astrocytes also reduced intercellular coupling in adult mice in situ, dye coupling was assessed in hippocampal slices using the patch-clamp technique. These experiments were performed in the CA1 stratum radiatum. To quantitatively evaluate the degree of coupling, we used the small molecular weight molecule biocytin $\left(M_{r} 372.5\right)$, which readily passes gap junctions. Seven hippocampal slices were obtained from $\mathrm{Cx} 43^{\mathrm{fl} / \mathrm{l}}$ mice and $\mathrm{Cx} 43^{\mathrm{fl} / \mathrm{fl}}$, hGFAP-cre mice each. A single astrocyte with a passive current phenotype (Kressin et al., 1995) was selected in the respective slice in the CA1 stratum radiatum (Fig. 5A,B, left panels). The resting potentials of astrocytes from $\mathrm{Cx} 43^{\mathrm{fl} / \mathrm{fl}}$ mice and $\mathrm{Cx} 43^{\mathrm{fl} / \mathrm{fl}}$, hGFAP-cre mice did not differ $(-70.8 \pm 1.4 \mathrm{mV} ; n=14)$ and remained stable (alteration $3 \pm 2 \mathrm{mV}$ ) during the $20 \mathrm{~min}$ period of recording.

Staining for biocytin revealed a significant decrease in intercellular coupling in $\mathrm{Cx} 43^{\mathrm{fl} / \mathrm{fl}}$, hGFAP-cre mice as compared with $\mathrm{Cx} 43^{\mathrm{fl} / \mathrm{fl}}$ mice (Fig. $5 \mathrm{~A}, \mathrm{~B}$, right panels). In the $\mathrm{Cx} 43^{\mathrm{fl} / \mathrm{fl}}$ mice, single astrocytes ( $n=7$ of 7 cells tested) coupled with a total of $233 \pm$ 52 neighboring cells whereas in mice with hGFAP-cre-mediated deletion of $C \times 43$, the degree of coupling was reduced by $50 \%$ $(119 \pm 30 ; n=7$ of 7 cells tested).

\section{Investigation of brain physiology: changes in spreading depression}

Induction of spreading depression

In slices of $\mathrm{Cx} 43^{\mathrm{H} / /+}$ as well as of $\mathrm{Cx} 43^{\mathrm{fl} /-}$ and $\mathrm{Cx} 43^{\mathrm{fl} /-}$, hGFAP-cre mice, $\mathrm{SD}$ could be induced by pressure injection of $\mathrm{K}^{+}$into st. radiatum of the CA1 region (Fig. 6A). Typical biphasic negative

$\leftarrow$

the propagation velocity in st. radiatum (white bars) was significantly accelerated in slices of $\mathrm{C} \times 43^{\mathrm{f} / /}$, hGFAP-cre mice compared with slices of $\mathrm{C} \times 43^{\mathrm{fl} /+}$ and $\mathrm{C} \times 43^{\mathrm{ft} /}$ - mice. $n$, number of mice analyzed. 


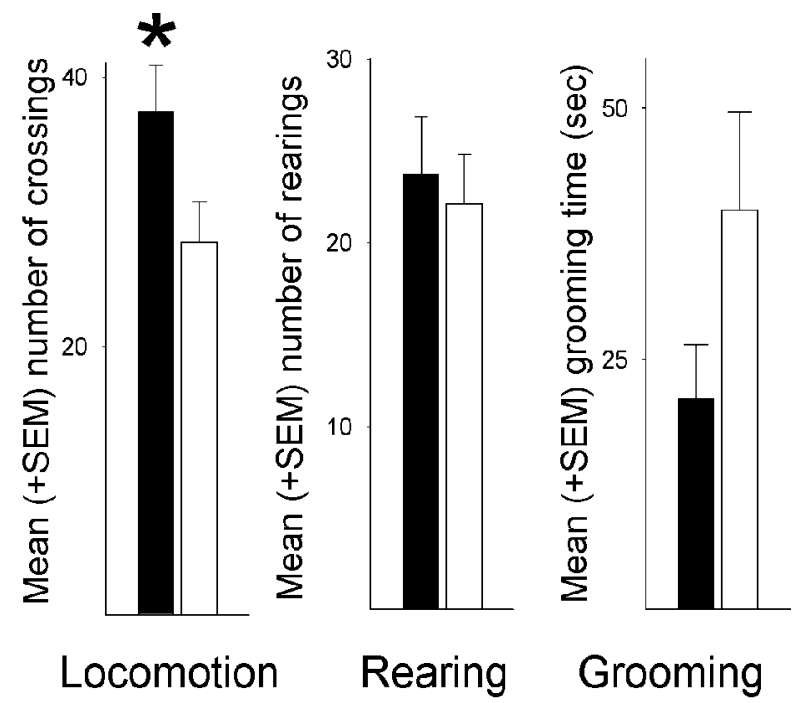

Figure 7. Behavioral alteration of $\left(x 43^{f / f f l}\right.$, hGFAP-cre mice in the small open field test. $\mathrm{C} \times 43^{\mathrm{fl} / \mathrm{fl}}$, hGFAP-cre mice (black bars) showed significantly (asterisk) increased horizontal locomotory activity compared with $\left(x 43^{\mathrm{fl} / \mathrm{fl}}\right.$ mice (white bars) when newly placed in a small open field, but no statistically significant differences in rearing and grooming behavior were apparent between both genotypes.

field potentials (fps) with average peak amplitudes of $17 \pm 1 \mathrm{mV}$ $\left(\mathrm{Cx} 43^{\mathrm{fl} /+}\right)$ and $14 \pm 1 \mathrm{mV}\left(\mathrm{Cx} 43^{\mathrm{fl} /-}\right.$ and $\mathrm{Cx} 43^{\mathrm{fl} /-}$, hGFAP-cre $)$, on average lasting for $54 \pm 15 \mathrm{sec}$ (all genotypes), accompanied by extracellular $\mathrm{K}^{+}\left(\left[\mathrm{K}^{+}\right]_{\mathrm{o}}\right)$ rises of $\sim 40 \pm 3 \mathrm{~mm}$ lasting for $67 \pm 6$ sec (all genotypes) were recorded at the distal electrode (Fig. 6A). Thus, the amplitudes of potassium-induced SD potentials varied between $\mathrm{Cx} 43^{\mathrm{fl} /+}$ and the other genotypes, whereas its duration and rises in $\left[\mathrm{K}^{+}\right]_{\mathrm{o}}$ were not significantly different for all genotypes (Table 2). The amplitudes of negative fps were significantly larger in $\mathrm{Cx} 43^{\mathrm{fl} /+}$ mice than in $\mathrm{Cx} 43^{\mathrm{fl} /-}$ and $\mathrm{Cx} 43^{\mathrm{fl} /-}$, hGFAP-cre mice (Table 2). Usually SD-associated negative fp shifts were preceded by a small positive $\mathrm{fp}$ shift with amplitudes of $<3 \mathrm{mV}$. The duration of these positive $\mathrm{fp}$ shifts varied between the different groups. They were $5.8 \pm 0.6 \mathrm{sec}$ in $\mathrm{Cx} 43^{\mathrm{fl} /+}$ mice, $7.1 \pm 0.4 \mathrm{sec}$ in $\mathrm{Cx} 43^{\mathrm{fl} /-}$ mice, and $8 \pm 0.4 \mathrm{sec}$ in $\mathrm{Cx} 43^{\mathrm{fl} /-}$, hGFAP-cre mice $\left(\mathrm{Cx} 43^{\mathrm{fl} /+}\right.$ significantly different from $\mathrm{Cx} 43^{\mathrm{fl} /-}$, hGFAP-cre). SDs could not be evoked in all slices, with the likelihood being somewhat larger in $\mathrm{Cx} 43^{\mathrm{fl} /-}$ mice and $\mathrm{Cx} 43^{\mathrm{fl} /-}$, hGFAP-cre mice compared with $\mathrm{Cx} 43^{\mathrm{fl} /+}$ mice. Thus SDs could be evoked in only 15 of 37 slices $(41 \%)$ of $\mathrm{Cx} 43^{\mathrm{fl} /+}$ mice, but in 12 of 20 slices $(60 \%)$ of $\mathrm{Cx} 43^{\mathrm{fl} /-}$ mice and in 17 of 29 slices $(59 \%)$ of $\mathrm{Cx} 43^{\mathrm{fl} /-}$, hGFAP-cre mice.

In all slices in which $\left[\mathrm{K}^{+}\right]_{\mathrm{o}}$ and fp changes at both electrodes indicated spreading depression, characteristic changes in slice transparency (intrinsic optical signal), which slowly spread across the slice, were noted. The onset of IOS (with pictures taken every second) compared well with the appearance of electrical signals, but the IOS recovered more slowly than the fp shifts and $\left[\mathrm{K}^{+}\right]_{\mathrm{o}}$ rises. The IOS wave propagated unidirectionally from the site of initiation near area CA3 along area CA1 toward the subiculum and mostly ended at the beginning of the subicular complex. SD waves did not invade the entorhinal cortex or the temporal neocortex bordering area CA1 and also did not propagate into the dentate gyrus across the hippocampal fissure. Thus, the SDs were restricted to st. oriens, st. pyramidale, and st. radiatum of area CA1. The pronounced decrease in light transmission with peak values of $\sim 9 \%$ (Fig. $6 \mathrm{~B}$ ) was followed by a gradual decline of the IOS. Decrease in transmission change was largest in st. radia- $\operatorname{tum}(9.3 \pm 0.5 \% ; n=48)$ and less in st. pyramidale $(6.8 \pm 0.6 \%$; $n=48)$ and st. oriens $(6.9 \pm 0.6 \% ; n=48)$. The amplitudes of IOS were not significantly different between the three groups.

Propagation velocities of SD

Analysis of the wave front of light transmission changes revealed different propagation velocities in st. radiatum and st. oriens/st. pyramidale (Fig. $6 \mathrm{~B}$ ). The SD propagation velocities in st. oriens/ st. pyramidale of $\mathrm{Cx} 43^{\mathrm{fl} /+}$ mice, $\mathrm{Cx} 43^{\mathrm{fl} /-}$ mice and $\mathrm{Cx} 43^{\mathrm{fl} /-}$, hGFAP-cre mice did not differ significantly from each other (Fig. $6 C$, Table 2). By contrast, the propagation velocity in st. radiatum was significantly accelerated in slices of $\mathrm{Cx} 43^{\mathrm{fl} /-}$, hGFAP-cre mice compared with slices of $\mathrm{Cx} 43^{\mathrm{fl} /+}$ and $\mathrm{Cx} 43^{\mathrm{fl} /-}$ mice (Fig. $6 \mathrm{C}, \mathrm{Ta}-$ ble 2).

\section{Investigation of animal behavior: enhanced locomotor activity}

As a first step toward assessing potential behavioral changes associated with the astrocyte-specific inactivation of $\mathrm{Cx} 43$, we observed activity in the open field test (Fig. 7). We found a significant increase in horizontally directed locomotor activity but no significant change in rearing. Although we observed a tendency for a decrease, self-directed behavior (grooming) was not significantly changed in $\mathrm{Cx} 43^{\mathrm{fl} / \mathrm{fl}}$, hGFAP-cre mice. Besides increased locomotory activity that might correspond to facilitated SD in the context of a subthreshold animal model (see Discussion), no obvious behavioral disturbances, possibly related to SD-like processes, were observed in $\mathrm{Cx} 43^{\mathrm{fl} / \mathrm{fl}}$, hGFAP-cre mice. Further studies on fear-related behavior, long-term memory, and motor coordination are under way.

\section{Discussion}

We integrated a silent lac $Z$ reporter gene into the floxed $C \times 43$ allele that is activated only after cre-mediated deletion of the floxed DNA, including the Cx43 coding region (Fig. 1). The activation is restricted to cells that display transcriptional activity of the $C \times 43$ gene, and the lac $Z$ activation is a dominant indicator of the loss of $\mathrm{Cx} 43$ expression. Furthermore, the efficiency of deletion was independent of the number of floxed alleles (Table 1). The hGFAP-cre-mediated deletion of the floxed $\mathrm{Cx} 43$ coding region occurred in $93 \%$ of all brain cells (Table 1), which included neurons and oligodendrocytes in addition to astrocytes (Zhuo et al., 2001).

By lac $Z$ activation on gene deletion, we found that the $h G F A P$ cre transgene targets loss of $\mathrm{Cx} 43$ expression specifically to astrocytes and ependymal cells as opposed to endothelial cells and leptomeningeal cells (Fig. 3). Cells of the vasculature and leptomeninges therefore belong to the remaining $7 \%$ of brain cells without deletion. Immunofluorescence analysis shows that the inactivation in astrocytes is complete (Fig. 2C). The remaining faint signal in immunoblot analysis most likely reflects expression of $\mathrm{Cx} 43$ in vascular and leptomeningeal cells (Fig. 2B, Table 1).

In cultured astrocytes (Fig. 4), we could essentially confirm the results obtained with $\mathrm{Cx} 43^{-1-}$ mice (Naus et al., 1997). In adult astrocytes in situ, the 50\% decrease of intercellular communication in hippocampal slices (Fig. 5) corresponded to complete cre-mediated deletion. Actually, a similar value of dye coupling was observed in organotypic slice cultures from $\mathrm{Cx} 43^{-1-}$ mice (Frantseva et al., 2002). A decrease in growth and saturation density of astrocyte cultures lacking Cx43 was observed (Fig. 4), similar to that reported by Naus et al. (1997) and Dermietzel et al. (2000), but we found no change of $\mathrm{Cx} 43^{\mathrm{fl} / \mathrm{fl}}$, hGFAP-cre astrocyte density in the adult state in vivo. Most likely, compensatory ef- 
fects on astrocytic growth control and gap junctional communication in the adult brain are exerted by other connexins described in astrocytes, i.e., Cx26, Cx30, Cx40, Cx45, and Cx46 (Dermietzel et al., 2000; Rash et al., 2000; Nagy et al., 2001). However, in adult heterozygous $\mathrm{Cx} 46$ mice that carry a lacZ gene replacing the $\mathrm{Cx} 46$ open reading frame (Gong et al., 1997), no obvious lacZ staining in astrocytes of a normal mouse brain could be detected (S.-Z. Xu and X. Gong, personal communication). Together with the finding of Dermietzel et al., (2000), which found unchanged Cx40 and $\mathrm{Cx} 45$ protein distribution in the cortex of newborn $\mathrm{Cx} 43$ deficient mice, our data (Fig. 5) show that among astrocytic connexins, only $\mathrm{Cx} 30$ is upregulated in mice lacking astrocytic $\mathrm{Cx} 43$.

We report that mice lacking astrocytic $\mathrm{Cx} 43$ display an accelerated SD propagation and reduced intercellular coupling in the stratum radiatum of the hippocampal CA1 region. SDs represent a combined reaction of neurons and glial cells to large elevations in $\left[\mathrm{K}^{+}\right]_{\mathrm{o}}$ and glutamate concentration (cf. Somjen et al., 1992) and are associated with large increases in $\left[\mathrm{K}^{+}\right]_{\mathrm{o}}$, whereas $\mathrm{Na}^{+}$, $\mathrm{Ca}^{2+}$, and $\mathrm{Cl}^{-}$enter neurons and glial cells (Nicholson, 1980; Somjen et al., 1992). As a consequence, water is shifted from the extracellular space (ECS) into intracellular compartments, which leads to cell swelling. This in turn induces a reduction of the ECS and thereby causes elevations in $\left[\mathrm{K}^{+}\right]_{\mathrm{o}}$ and extracellular glutamate concentration. These changes could be involved in the generation of intrinsic optical signals that lead to transparency changes (Snow et al., 1983; Holthoff and Witte, 1996; Basarsky et al., 1998; Világi et al., 2001).

Gap junctions seem to play a central role in mechanisms that underlie initiation and propagation of SD. Gap junction blockers such as octanol, halothane, or heptanol were shown to reduce SD propagation velocity or to even block initiation of SD (Nedergaard et al., 1995). These drugs block unspecifically both neuronal and glial gap junctions. Martins-Ferreira and Ribeiro (1995) observed a biphasic, dose-dependent effect of heptanol and octanol on SD. Low concentrations led to an increase of SD velocity, whereas higher doses blocked SD completely. We obtained one aspect of the reported biphasic effect by a very specific inhibition of gap junction intercellular communication (GJIC), which was restricted to $\mathrm{Cx} 43$ in astrocytes. Therefore, the astrocyte-directed inactivation of $\mathrm{Cx} 43$ represents a new approach to investigate those mechanisms more precisely. Actually, our results indicate that the modulation of $\mathrm{Cx} 43$-containing gap junctions exerted on $\mathrm{SD}$ is more selective than that of gap junctions blocked by general inhibitors (Martins-Ferreira et al., 2000).

Astrocytes modulate extracellular glutamate concentration, thereby contributing to extracellular neurotransmitter homeostasis and astrocyte-neuron signaling (cf. Anderson and Swanson, 2000). Cx43-containing astrocytic gap junctions might support astrocytic glutamate uptake (Hansson et al., 2000). Indeed, impaired glutamate transport in astrocytes has been observed on gap junction uncoupling (Blanc et al., 1998), and locally enhanced extracellular glutamate might contribute to the accelerated spread of SD. Gap junction-coupled glial cells also have a role in regulation of $\left[\mathrm{K}^{+}\right]_{\mathrm{o}}$ (Orkand et al., 1966; Ransom, 1996; Amzica et al., 2002). When $\left[\mathrm{K}^{+}\right]_{\mathrm{o}}$ is elevated locally, the glial cells become depolarized, and this depolarization spreads through gap junctions into the neighboring astrocytes. In this way $\mathrm{K}^{+}$diffusion is strongly accelerated in all directions of space. This spatial buffering mechanism is also involved in generation of slow negative fps (Dietzel et al., 1989).

We suggest that mice lacking $\mathrm{Cx} 43$ in astrocytes, with significantly reduced intercellular dye coupling, show deficient redistribution of $\mathrm{K}^{+}$in lateral directions and toward the surface of the slices (Fig. 6, Table 2). This would be expected to lead to a more abrupt local rise of $\left[\mathrm{K}^{+}\right]_{\mathrm{o}}$, resulting in a faster attainment of SD threshold conditions in st. radiatum, where indeed the propagation velocity of SD was found to be accelerated by $20 \%$. This would also result in a reduced capability to generate slow negative field potentials, which is in line with our results. In addition, the threshold for induction of SDs was affected. SDs could be induced more easily, and the positive potentials that preceded the onset of SDs in st. pyramidale were significantly longer in $\mathrm{Cx} 43^{\mathrm{fl} /-}$ and $\mathrm{Cx} 43^{\mathrm{fl} /-}$, hGFAP-cre mice than in $\mathrm{Cx} 43^{\mathrm{fl} /+}$ mice. This positive potential recorded in st. pyramidale might be caused by strong depolarization of pyramidal cell dendrites, which electrotonically leads to generation of a positive extracellular field potential near the somata of pyramidal cells. Because the propagation velocity was accelerated in st. radiatum but not in st. oriens/ pyramidale, the increased delay in the propagation of SDs in these layers could account for the prolonged positive potential preceding onset of SD. St. radiatum seems to be more prone to impairment of mechanisms underlying SD. Herreras and Somjen (1993) also described propagation velocity of SDs in area CA1 that was faster and sensitivity of SD waves to NMDA receptor antagonists that was larger in st. radiatum than in st. pyramidale.

The reason for the restricted nature of the observed effects on SD attributable to lack of $\mathrm{Cx} 43$ in astrocytes might be a functional compensation by another astrocytic connexin(s), most likely Cx30 (Fig. 5). Certainly, other mechanisms such as extracellular purinergic signaling (cf. Cotrina et al., 2000; Martins-Ferreira et al., 2000; Kukley et al., 2001) or neuronal gap junctions (Largo et al., 1997) also might have contributed to the modulated SD propagation that we observed. Kunkler and Kraig (1998) discuss a fast neuronal calcium wave and a slow astrocytic calcium wave preceding SD mediated by gap junctions. Although astrocytic calcium waves are propagated by purinergic signaling, they are greatly enhanced by the presence of connexins (Cotrina et al., 2000), probably because of ATP release through hemichannels (Stout et al., 2002). Most likely, astrocytic GJIC mediated by Cx43 attenuates SD propagation by efficiently decreasing $\left[\mathrm{K}^{+}\right]_{\mathrm{o}}$ or extracellular glutamate concentration, but at the same time, $\mathrm{Cx} 43$ together with $\mathrm{Cx} 30$ also mediates SD propagation by enhancing purinergic propagation of astrocytic calcium waves. In mice lacking $\mathrm{Cx} 43$ in astrocytes, threshold concentrations for propagation of SD are attained more easily, whereas Cx30 still supports propagation of calcium waves. The combined inactivation of $\mathrm{Cx} 43$ and Cx30 in astrocytes is suited to proving this hypothesis and a prerequisite to investigating the possible contribution of neuronal gap junctions to SD.

Because SD is correlated with pathophysiological phenomena that often coincide with behavioral changes (Martins-Ferreira et al., 2000; James et al., 2001), we assessed animal behavior in the small open field test (Fig. 7). Mice lacking Cx43 in astrocytes showed increased locomotor activity, which was observed previously in rats experiencing SD after intrahippocampal injection of $\mathrm{KCl}$ in vivo (Oitzl and Huston, 1984). In contrast to the previous report, which showed a significant increase in grooming activity, we observed instead a (nonsignificant) tendency for decreased grooming activity. Accelerated SD and enhanced locomotory activity might represent a mild form of the behavioral and electrophysiological responses observed after intrahippocampal injection of $\mathrm{KCl}$ in rats (Oitzl and Huston, 1984), possibly related to a generally increased neuronal excitation by activity-related increases in extracellular potassium and glutamate concentrations. The decrease in grooming, untypical for SD-related behavior (Huston and Holzhäuer 1988), points to further effects of the 
astrocyte-directed $\mathrm{Cx} 43$ inactivation specifically counteracting an increase in grooming. For example, changes in oscillatory patterns of Cx43-deficient astrocyte assemblies (Bloomstrand et al., 1999) might affect neuronal oscillation patterns, which are proposed to be related to exploratory and adaptive behavior as well as memory consolidation (Buzsaki 1989; Buzsaki and Chrobak, 1995). Because calcium elevations in hippocampal astrocytes modulate neuronal activity (Araque et al., 1998), the brain astrocyte compartment might thereby exert a direct influence on neuronal behavioral control. These effects might be related to conditioning processes, as, for example, a potentiation of astrocytic calcium oscillations induced by neuronal stimulation (Pasti et al., 1997). The involvement of Cx43 in this putative link between astrocyte activity and animal behavior is currently being investigated in our laboratories.

\section{References}

Amzica F, Massimini M, Manfridi A (2002) Spatial buffering during slow and paroxysmal sleep oscillations in cortical networks of glial cells in vivo. J Neurosci 22:1042-1053.

Anderson CM, Swanson RA (2000) Astrocyte glutamate transport: review of properties, regulation, and physiological functions. Glia 32:1-14.

Araque A, Parpura V, Sanzgiri RP, Haydon PG (1998) Glutamatedependent astrocyte modulation of synaptic transmission between cultured hippocampal neurons. Eur J Neurosci 10:2129-2142.

Basarsky TA, Duffy SN, Andrew RD, MacVicar BA (1998) Imaging spreading depression and associated intracellular calcium waves in brain slices. J Neurosci 18:7189-7199.

Betz UA, Vosshenrich CA, Rajewsky K, Muller W (1996) Bypass of lethality with mosaic mice generated by Cre-loxP-mediated recombination. Curr Biol 6:1307-1316.

Blanc EM, Bruce-Keller AJ, Mattson MP (1998) Astrocytic gap junction communication decreases neuronal vulnerability to oxidative stressinduced disruption of $\mathrm{Ca}^{2+}$ homeostasis and cell death. J Neurochem 70:958-970.

Bloomstrand F, Aberg ND, Eriksson PS, Hansson E, Rönnbäck L (1999) Extent of intercellular calcium wave propagation is related to gap junction permeability and level of connexin- 43 expression in astrocytes in primary cultures from four brain regions. Neuroscience 92:255-265.

Buchheim K, Schuchmann S, Siegmund H, Weissinger F, Heinemann U, Meierkord H (2000) Comparison of intrinsic optical signals associated with low $\mathrm{Mg}^{2+}$-4-aminopyridine-induced seizure-like events reveals characteristic features in adult rat limbic system. Epilepsia 41:635-641.

Buzsaki G (1989) Two-stage model of memory trace formation: a role for "noisy" brain states. Neuroscience 31:551-570.

Buzsaki G, Chrobak JJ (1995) Temporal structure in spatially organized neuronal ensembles: a role for interneuronal networks. Curr Opin Neurobiol 5:504-510.

Butterweck A, Gergs U, Elfgang C, Willecke K, Traub O (1994) Immunochemical characterization of the gap junction protein connexin 45 in mouse kidney and transfected human HeLa cells. J Membr Biol 141:247-256.

Contreras JE, Sanchez HA, Eugenin EA, Speidel D, Theis M, Willecke K, Bukauskas FF, Bennett MV, Saez JC (2002) Metabolic inhibition induces opening of unapposed connexin 43 gap junction hemichannels and reduces gap junctional communication in cortical astrocytes in culture. Proc Natl Acad Sci USA 99:495-500.

Cotrina ML, Lin JH, Lopez-Garcia JC, Naus CC, Nedergaard M (2000) ATP-mediated glia signaling. J Neurosci 20:2835-2844.

D’Ambrosio R, Wenzel J, Schwartzkroin PA, McKhann II GM, Janigro D (1998) Functional specialization and topographic segregation of hippocampal astrocytes. J Neurosci 18:4425-4438.

Dermietzel R, Traub O, Hwang TK, Beyer E, Bennett MV, Spray DC, Willecke K (1989) Differential expression of three gap junction proteins in developing and mature brain tissues. Proc Natl Acad Sci USA 86:10148-10152.

Dermietzel R, Gao Y, Scemes E, Vieira D, Urban M, Kremer M, Bennett MVL, Spray DC (2000) Connexin43 null mice reveal that astrocytes express multiple connexins. Brain Res Rev 32:45-56.

Dietzel I, Heinemann U, Lux HD (1989) Relations between slow extracellular potential changes, glial potassium buffering, and electrolyte and cellu- lar volume changes during neuronal hyperactivity in cat brain. Glia 2:25-44.

Dreier JP, Heinemann U (1991) Regional and time dependent variations of low $\mathrm{Mg}^{2+}$ induced epileptiform activity in rat temporal cortex slices. Exp Brain Res 87:581-596.

Frantseva MV, Kokarovtseva L, Naus CG, Carlen PL, MacFabe D, Perez Velazquez JL (2002) Specific gap junctions enhance the neuronal vulnerability to brain traumatic injury. J Neurosci 22:644-653.

Gabriel HD, Jung D, Bützler C, Temme A, Traub O, Winterhager E, Willecke K (1998) Transplacental uptake of glucose is decreased in embryonic lethal connexin26-deficient mice. J Cell Biol 140:1453-1461.

Gong X, Li E, Klier G, Huang Q, Wu Y, Lei H, Kumar NM, Horwitz J, Gilula NB (1997) Disruption of alpha3 connexin gene leads to proteolysis and cataractogenesis in mice. Cell 91:833-843.

Hansson E, Muyderman H, Leonova J, Allansson L, Sinclair J, Blomstrand F, Thorlin T, Nilsson M, Ronnback L (2000) Astroglia and glutamate in physiology and pathology: aspects on glutamate transport, glutamateinduced cell swelling and gap-junction communication. Neurochem Int 37:317-329.

Herreras O, Somjen GG (1993) Propagation of spreading depression among dendrites and somata of the same cell population. Brain Res 610:276-282.

Holthoff K, Witte OW (1996) Intrinsic optical signals in rat neocortical slices measured with near-infrared dark-field microscopy reveal changes in extracellular space. J Neurosci 16:2740-2749.

Houghton FD, Thönnissen E, Kidder GM, Naus CC, Willecke K, Winterhager E (1999) Doubly mutant mice, deficient in connexin32 and -43 , show normal prenatal development of organs where the two gap junction proteins are expressed in the same cells. Dev Genet 24:5-12.

Huston JP, Holzhäuer MS (1988) Behavioral and electrophysiological effects of intracranially applied neuropeptides with special attention to DC slow potential changes. Ann NY Acad Sci 525:375-390.

James MF, Smith JM, Boniface SJ, Huang CL, Leslie RA (2001) Cortical spreading depression and migraine: new insights from imaging? Trends Neurosci 24:266-271.

Kästner KH, Montoliu L, Kern H, Thulke M, Schütz G (1994) Universal beta-galactosidase cloning vectors for promoter analysis and gene targeting. Gene 148:67-70.

Kirchhoff S, Nelles E, Hagendorff A, Kruger O, Traub O, Willecke K (1998) Reduced cardiac conduction velocity and predisposition to arrhythmias in connexin40-deficient mice. Curr Biol 8:299-302.

Kressin K, Kuprijanova E, Jabs R, Seifert G, Steinhäuser C (1995) Developmental regulation of $\mathrm{Na}^{+}$and $\mathrm{K}^{+}$conductances in glial cells of mouse hippocampal brain slices. Glia 15:173-187.

Krüger O, Plum A, Kim JS, Winterhager E, Maxeiner S, Hallas G, Kirchhoff S, Traub O, Lamers WH, Willecke K (2000) Defective vascular development in connexin 45-deficient mice. Development 127:4179-4193.

Kukley M, Barden JA, Steinhäuser C, Jabs R (2001) Distribution of P2X receptors on astrocytes in juvenile rat hippocampus. Glia 36:11-21.

Kumar NM, Gilula NB (1996) The gap junction communication channel. Cell 84:381-388.

Kunkler PE, Kraig RP (1998) Calcium waves precede electrophysiological changes of spreading depression in hippocampal organ cultures. J Neurosci 18:3416-3425.

Largo C, Tombaugh GC, Aitken PG, Herreras O, Somjen GG (1997) Heptanol but not fluoroacetate prevents the propagation of spreading depression in rat hippocampal slices. J Neurophysiol 77:9-16.

Loewenstein WR (1981) Junctional intercellular communication: the cellto-cell membrane channel. Physiol Rev 61:829-913.

Lux HD, Neher E (1973) The equilibration time course of $\left[\mathrm{K}^{+}\right]_{\mathrm{o}}$ in cat cortex. Exp Brain Res 17:190-205.

Martins-Ferreira H, Ribeiro LJ (1995) Biphasic effects of gap junctional uncoupling agents on the propagation of retinal spreading depression. Braz J Med Biol Res 28:991-994.

Martins-Ferreira H, Nedergaard M, Nicholson C (2000) Perspectives on spreading depression. Brain Res Rev 32:215-234.

Nagy JI, Li X, Rempel J, Stelmack G, Patel D, Staines WA, Yasumura T, Rash JE (2001) Connexin26 in adult rodent central nervous system: demonstration at astrocytic gap junctions and colocalization with connexin30 and connexin43. J Comp Neurol 441:302-323.

Naus CCG, Bechberger JF, Zhang Y, Venance L, Yamasaki H, Juneja SC, Kidder GM, Giaume C (1997) Altered gap junctional communication, 
intercellular signaling and growth in cultured astrocytes deficient in connexin43. J Neurosci Res 49:528-540.

Nedergaard M, Cooper AJL, Goldman SA (1995) Gap junctions are required for the propagation of spreading depression. J Neurobiol 28:433-444.

Nicholson C (1980) Dynamics of the brain cell microenvironment. Neurosci Res Prog Bull 18:175-322.

Oitzl MS, Huston JP (1984) Electroencephalographic spreading depression and concomitant behavioral changes induced by intrahippocampal injections of ACTH1-24 and D-Ala2-Met-enkephalinamide in the rat. Brain Res 308:33-42.

Orkand RK, Nicholls JG, Kuffler SW (1966) Effect of nerve impulses on the membrane potential of glial cells in the central nervous system of amphibia. J Neurophysiol 29:788-806.

Pasti L, Voterra A, Pozzan T, Carmignoto G (1997) Intracellular calcium oscillations in astrocytes: a highly plastic, bidirectional form of communication between neurons and astrocytes in situ. J Neurosci 17:7817-7830.

Ransom BR (1996) Do glial gap junctions play a role in extracellular ion homeostasis? In: Gap junctions in the nervous system (Spray DC, Dermietzel R, eds), pp 159-173. Heidelberg: Springer.

Rash JE, Staines WA, Yasumura T, Patel D, Furman CS, Stelmack GL, Nagy JI (2000) Immunogold evidence that neuronal gap junctions in adult rat brain and spinal cord contain connexin-36 but not connexin-32 or connexin-43. Proc Natl Acad Sci USA 97:7573-7578.

Reaume AG, de Sousa PA, Kulkarni S, Langille BL, Zhu D, Davies TC, Juneja SC, Kidder GM, Rossant J (1995) Cardiac malformation in neonatal mice lacking connexin43. Science 267:1831-1834.
Rouach N, Glowinski J, Giaume C (2000) Activity-dependent neuronal control of gap-junctional communication in astrocytes. J Cell Biol 149:1513-1526.

Scemes E, Dermietzel R, Spray DC (1998) Calcium waves between astrocytes from Cx43 knockout mice. Glia 24:65-73.

Snow RW, Taylor CP, Dudek FE (1983) Electrophysiological and optical changes in slices of rat hippocampus during spreading depression. J Neurophysiol 50:561-572.

Somjen GG, Aitken PG, Czeh GL, Herreras O, Jing J, Young JN (1992) Mechanisms of spreading depression: a review of recent findings and a hypothesis. Can J Physiol Pharmacol 70:S248-S254.

Steinhäuser C, Berger T, Frotscher M, Kettenmann H (1992) Heterogeneity in the membrane current pattern of identified glial cells in the hippocampal slice. Eur J Neurosci 4:472-484.

Stout CE, Costantin JL, Naus CC, Charles AC (2002) Intercellular calcium signaling in astrocytes via ATP release through connexin hemichannels J Biol Chem 277:10482-10488.

Theis M, de Wit C, Schlaeger TM, Eckardt D, Krüger O, Döring B, Risau W, Deutsch U, Pohl U, Willecke K (2001) Endothelium-specific replacement of the connexin 43 coding region by a lacZ reporter gene. Genesis 29:1-13.

Világi I, Klapka N, Luhmann HJ (2001) Optical recording of spreading depression in rat neocortical slices. Brain Res 898:288-296.

Zhuo L, Theis M, Maya-Alvarez I, Brenner M, Willecke K, Messing A (2001) hGFAP-cre transgenic mice for manipulation of glial and neuronal function in vivo. Genesis 31:85-94. 